\title{
EL IDEAL MILITAR HISPÁNICO: UNA PROPUESTA SOBRE TRANSFERENCIAS SOCIOCULTURALES Y LITERARIAS DE la Castilla Medieval a la conQuista española DE AMÉRICA ${ }^{1}$
}

\author{
Víctor MuÑoz GómeZ² \\ IEMyR. Universidad de La Laguna
}

Recibido: 9 de junio de 2019

Aceptado: 6 de septiembre de 2019

\begin{abstract}
Resumen
En este artículo se estudiarán las características del mando militar desempeñado por los reyes de Castilla durante la Baja Edad Media en relación con su ejercicio en las campañas contra los musulmanes especialmente entre el reinado de Alfonso XI y la conquista de Granada por los Reyes Católicos. Estas cualidades se hallaron fuertemente vinculadas a un discurso legitimador de la monarquía en torno a los principios de la "recuperación de España", la Cruzada y la Caballería. A partir de su análisis en los textos cronísticos de los siglos XIV y XV, se propone la hipótesis de que ese modelo medieval de liderazgo militar monárquico, ligado al citado marco ideológico, pudo ser recogido en los relatos de las crónicas de Indias y, paralelamente, haber sido integrado por los capitanes de la conquista de América.
\end{abstract}

\section{Palabras clave}

Crónicas, Rey, Mando militar, Castilla, América.

\begin{abstract}
This paper aims to study the features of the military command that was exerted by the kings of Castile in Late Middle Ages with respect to its performance during the campaigns against the Muslims, particularly from the reign of king Alfonso XI to the conquest of Granada by the Catholic Kings. These military traits were strongly associated to the notions of 'the recovery of Spain' (restauratio Hispaniae, 'Reconquista'), Crusade and Chivalry. From its analysis through $14^{\text {th }}-15^{\text {th }}$ centuries chronistical texts, we propose the hypothesis that this medieval model of monarchical military leadership, linked to the aforementioned ideological framework, could have been reflected in the narrative of the 'Crónicas de Indias' and concurrently have been assumed by the Spanish captains of the Conquest of America.
\end{abstract}

Este trabajo forma parte del proyecto de investigación El mar como frontera. Transgresiones legales en el Atlántico bajomedieval (Ref. PGC2018-095719-B-I00), financiado por el Ministerio de Ciencia, Innovación y Universidades

2 Dpto. Geografía e Historia. Instituto de Estudios Medievales y Renacentistas. Universidad de La Laguna. Correo electrónico: vmunozgo@ull.edu.es. OrCiD: https://orcid.org/0000-0002-6680-4103. 


\section{Keywords}

Chronicles, King, Military Leadership, Castile, America.

\section{Résumé}

Dans cet article, on se propose d'étudier les pratiques du commandement militaire adoptées par les rois de Castille pendant le Bas Moyen Âge dans leurs campagnes contre les musulmans et plus précisément du règne d'Alphonse XI à la conquête de Grenade par les Rois Catholiques. Ces pratiques sont étroitement associées à un discours visant à légitimer les concepts de «récupération», de «croisade» et de «chevalerie». En partant des chroniques des xiv ${ }^{\mathrm{e}}$ et $\mathrm{xv}^{\mathrm{e}}$ siècles, on défendra l'hypothèse selon laquelle le modèle médiéval, qui veut que le pouvoir militaire relève du monarque, a pu être assimilé par les conquistadors et repris dans les Chroniques des Indes.

\section{Mots-clés}

Chroniques, roi, commandement militaire, Castille, Amérique.

\section{Introducción}

Gonzalo Fernández de Oviedo, primer cronista de Indias, en 1535, no dudaba, al iniciar su Historia Natural y General de las Indias, en situar el origen del señorío que correspondía a los reyes de España sobre las tierras del Nuevo Mundo mucho más allá del resultado de los pioneros viajes oceánicos capitaneados por Cristóbal Colón y de la sanción del papa a tal dominio. Sus raíces se hundían nada menos que en los albores de la Antigüedad mítica. Así, basándose en el falso Berosio publicado por Annio de Viterbo en $1498^{3}$, atribuyó el descubrimiento de las islas Hespérides, que identificaba con las Antillas, a Hespero, duodécimo rey de España, hacía tres mil ciento noventa y tres años. De este modo,

assi con derecho tan antiquissimo, por la forma que está dicha, por la que adelante se dirá en la prosecución de los viajes del almirante Chripstobal Colom, volvio Dios este señorio á España a cabo de tantos siglos. E paresçe que, como cosa que fue suya, quiere la divina justicia que lo haya tornado á ser é lo sea perpetuamente, en ventura de los bienaventurados é Cathólicos Reyes, don Fernando é doña Isabel, que ganaron á Granada é Nápoles, etc. ${ }^{4}$

David Brading interpreta con buen criterio el objetivo discursivo de Fernández de Oviedo de hacer de esta empresa no una nueva expansión de la monarquía, sino que “...la ocupación del Nuevo Mundo por los españoles debía considerarse la reconquista de antiguos dominios ibéricos..." $"$. No solo los ecos de la conquista final de Granada

GonzÁlez DíAz, “Genealogía de un origen”, pp. 509-514.

Fernández de Oviedo, Historia General y Natural de las Indias, vol. I, pp. 14-18.

5 Brading, Orbe indiano, pp. 47-48. 
en 1492 eran aún cercanos entre los contemporáneos del emperador Carlos V sino que la significación de la guerra emprendida por los poderes hispánicos contra los musulmanes, fundamentalmente liderada por Castilla en la Baja Edad Media, había caracterizado y seguía caracterizando la identidad de la monarquía de España, de sus sociedades y súbditos.

El objeto de estas páginas no es, en todo caso, el debate en torno al concepto historiográfico de "Reconquista" y los procesos históricos a los que remite. Ahora bien, alrededor de esta discusión me interesa aquí llamar la atención sobre una de las acepciones del término, la cual justamente remite al plano ideológico de legitimación de la guerra expansiva liderada por las monarquías cristianas del norte de la Península Ibérica sobre los territorios musulmanes andalusíes en términos de restauratio Hispaniae, es decir, de recuperación del reino perdido de los godos a manos de los infieles ${ }^{6}$. Este principio, a partir de los siglos XI y XII, fue integrando de forma progresiva elementos del discurso de guerra santa y cruzada alimentado desde el papado alrededor de la recuperación de Tierra Santa, la lucha contra los enemigos no cristianos y la defensa de la Cristiandad ${ }^{7}$. De este modo, desde el siglo XIII y, sobre todo, el siglo XIV, en la monarquía castellano-leonesa -la que de forma más intensiva asumió como propia esa misión de la "restauración de España"-, los argumentarios de guerra santa y de guerra justa para la recuperación de la tierra invadida ilegítimamente por un enemigo extranjero tendieron a subsumirse el uno en el otro, apoyándose mutuamente a la hora de justificar el liderazgo de los reyes en unas empresas expansivas hacia el sur contra los oponentes granadinos y norteafricanos que cumplían al servicio de Dios y la Iglesia, del propio rey y del reino ${ }^{8}$.

Precisamente, sobre ese papel del monarca como caudillo del reino y comandante de la hueste frente a los musulmanes me gustaría centrar este trabajo. No en vano, en el medievo ibérico, la función del rey como tal líder militar de sus vasallos y naturales, muy particularmente en las acciones de guerra con el Islam, resultó ser una de las principales que correspondían al ejercicio del poder regio y sobre la que en gran medida se justificaba su autoridad y prestigio, presente y para la posteridad, en la ostentación

\footnotetext{
6 Valga señalar que considero las dinámicas de ocupación militar y organización social del espacio por parte de las sociedades cristianas feudales de la Península Ibérica a despecho de las de al-Andalus como insertas en un proceso más global de expansión de la sociedad feudal cristiana occidental desde la Plena Edad Media, si bien con sus especificidades, mejor que como un fenómeno original y exclusivamente hispánico, diferenciado de otros casos europeos. Sobre estos debates y estas posturas, amén de la cuestión del discurso de la "recuperación de España", BARTLETT, The Making of Europe; Torró, "Pour en finir avec la 'Reconquête"; O'Callaghan, Reconquest and Crusade in Medieval Spain; García Fitz, La Reconquista; Ríos SAloma, La reconquista: una construcción historiográfica, en particular pp. 30 y ss.; IDEM, La Reconquista en la historiografía española contemporánea.

7 Véase, al menos, con carácter general, sobre la idea de guerra santa y cruzada en el Occidente medieval, FLoRI, La guerre sainte, IDEM, Guerre sainte, jihad, croisade.

8 La bibliografía al respecto es muy abundante. Un buen ejemplo de ello en las referencias de la nota anterior, Ayala Martínez, "Órdenes militares y guerra santa. Reconquista y cruzada en el Occidente peninsular (siglos XII-XV)", o Henriet, "La guerra contra el Islam: una guerra santa, pero ¿según qué criterios?". Valga remitir a una síntesis al respecto en Tinoco DíAz, "Aproximación a la cruzada", IDEM, La Cruzada en las fuentes cronísticas castellanas, pp. 33-68.
} 
de tal dignidad ${ }^{9}$. Así, el rey y la imagen de él al frente de la hueste -al servicio de la derrota de los musulmanes muy particularmente- venía a constituirse en un modelo, de gobernante y en el propio ejercicio de las armas para la comunidad del reino, que en el caso de Castilla alcanzó en buena medida su culmen en la figura de Fernando el Católico durante la guerra de conquista de Granada (1482-1492). La escenificación y comunicación de las cualidades virtuosas que adornaban al rey guerrero se convirtieron así en uno de los pilares legitimadores del poder de la monarquía castellana en la Baja Edad Media ${ }^{10}$. Mi intención es, pues, tratar de poner en relación ese modelo de mando militar regio castellano, conformado en torno a los enfrentamientos con los musulmanes, y la idea de continuidad "reconquistadora" que Brading interpretaba en las palabras del cronista Fernández de Oviedo acerca de los fenómenos de exploración, conquista y colonización de América por los españoles desde el final del siglo XV y los inicios del siglo XVI. Así, atendiendo a preocupaciones correspondientes tanto a los estudios históricos como a aquellos de carácter literario, se pretende hacer repaso al conocimiento actual acerca de las características militares que correspondían a los monarcas de Castilla a lo largo de los siglos XIV y XV y su articulación armónica alrededor de los ideales que afectaron a la guerra contra el Islam en la Península Ibérica. Para ello, recurriré a su valoración global a partir de los testimonios plasmados en la narrativa cronística regia desde la época de Alfonso XI hasta la de los Reyes Católicos, cuyo análisis más específico pude abordar recientemente ${ }^{11}$.

La selección de estas fuentes obedece, en fin, a diferentes consideraciones. La primera de ellas es de tipo conceptual, a la hora de considerar los materiales cronísticos a analizar. No en vano, estos relatos se hallaban caracterizados por el poderoso sentido ideológico de los mismos, resultando una "lógica social" de dichos textos bien integrada con los valores de construcción y legitimación de la centralidad de la monarquía en la cúspide de la sociedad feudal tardomedieval. Estos, significativamente impulsados desde los entornos regios castellanos a partir de la época de Alfonso X como parte de un programa integral, progresivamente terminarían imponiéndose en el conjunto del reino de la mano de la construcción de un relato historiográfico del mismo que giraba, en efecto, en torno al protagonismo de la monarquía y sus titulares, los valores por ellos propugnados y los acontecimiento ligados a aquellos en el seno de la narración cronística y de la propia memoria del reino ${ }^{12}$.

Con todo, el ejercicio de la guerra contra los musulmanes liderada por parte del monarca es un elemento de notable relevancia en la narrativa historiográfica del Occidente

\footnotetext{
Maravall, El concepto de España, p. 263.

10 Nieto Soria, Ceremonias de la realeza.

11 MuÑoz Gómez, "La construcción de un modelo de liderazgo militar".

12 Gómez Redondo, "Historiografía medieval: constantes evolutivas de un género"; Spiegel, "History, Historicism, and the Social Logic of the Text in the Middle Ages"; Gómez Redondo, "La construcción del modelo de crónica real"; WARD, Teoría y práctica de la historiografía medieval ibérica, FunEs, "De Alfonso el Sabio al Canciller Ayala: variaciones del relato histórico"; VALDALiso CASANOvA, "La legitimación dinástica", IDEM, Historiografía y legitimación dinástica, pp. 155-192; IDEM, "Discursos de legitimación”.
} 
peninsular ibérico ya desde época astur-leonesa. No en vano, las crónicas asturianas y otras fuentes de los siglos IX-XI expresaron su consideración como una guerra sacralizada que obedecía a la voluntad de Dios bajo la dirección del rey para la reintegración del pueblo cristiano en la gracia divina perdida con la derrota de Rodrigo y los godos frente a los musulmanes ${ }^{13}$. Así, a partir de un sustrato veterotestamentario, agustiniano y visigótico, el caudillaje regio en esa guerra para una ideal de recuperación de la España de los visigodos -restauratio Hispaniae-operó en los textos cronísticos como un formidable argumento de afirmación de la superioridad regia, al cual, desde el siglo XII, se irían incorporando términos y principios propios del discurso de cruzada, desde la Chronica Adefonsi imperatoris hasta el conjunto de la cronística latina y romance castellanoleonesa del siglo XIII y los inicios del siglo XIV ${ }^{14}$. Pese a esto, no fue sino en la producción historiográfica de la corte de Alfonso XI cuando se introdujeron finalmente de forma explícita todo el vocabulario -incluidos términos como "romería" o el mismo de "cruzada"- y la simbología - la toma de la cruz, el pendón, etc.- de la cruzada como soporte ideológico a la par de aquellos que tenían que ver con los principios de la "restauración de España"15.

A resultas de ello, parece razonable ceñirse a los materiales cronísticos propuestos, desde aquellos producidos en el reinado de Alfonso XI hasta los correspondientes al tiempo de los Reyes Católicos, como particularmente aptos para aproximarnos a la elaboración de las representaciones militares vinculadas a las empresas "restauradoras" y cruzadas de las guerras contra los musulmanes que aquí interesan. A su vez, a partir de la realización de esta exégesis, es posible formular una hipótesis de trabajo referida a esa dimensión de continuidad de la guerra de conquista hispánica desde los tiempos medievales hacia los de la Modernidad y del Viejo Mundo al Nuevo que era apreciada por los contemporáneos de Fernández de Oviedo y tenía en autores como él su plasmación historiográfica ${ }^{16}$.

De este modo, de existir el modelo de representación del liderazgo militar al que me vengo refiriendo y ser aprehensible a través de la cronística castellana bajomedieval, ¿sería posible tratar de hallar, dentro del nuevo contexto de expansión europea, mediterránea e indiana de la monarquía española de los Reyes Católicos y sus herederos y de los valores

\footnotetext{
13 Para un acercamiento actualizado a la cuestión, BRONISCH, Reconquista y guerra santa; IDEM, "La (sacralización de la) guerra".

14 Baloup, "Reconquête et croisade"; Ayala Martínez, Henriet, Palacios Ontalva (dir.) Orígenes y desarrollo de la guerra santa. Véase igualmente Fernández Gallardo, "Los Godos", donde se abunda sobre la evolución del goticismo en la historiografía castellana hasta el siglo XV.

15 Particularmente ilustrativos a este respecto resultan los trabajos PorRInAs GonZÁlez, "Guerra santa y cruzada", y FernÁndez Gallardo, Guerra santa, aun considerando que la cronística castellana hasta el final de la Edad Media privilegió con claridad la primacía de los monarcas como líderes indiscutibles del enfrentamiento contra los musulmanes de la Península Ibérica frente a la iniciativa y las atribuciones papales.

16 De particular interés al respecto, tanto por lo que se refiere a las definiciones de guerra justa como a los valores caballerescos y aristocráticos vinculados a la guerra de conquista contra infieles en el contexto europeo y americano del siglo XVI, las consideraciones sobre las obras de Gonzalo Fernández de Oviedo y Francisco López de Gómara en BÉNAT-TACHOT, Figura y configuración de "enemigo americano". Habrá ocasión de volver sobre estas cuestiones más adelante.
} 
que la alumbraron, un trasvase de esas cualidades guerreras y de mando a los capitanes de la conquista americana? ¿Sirvió, pues, el género cronístico bajomedieval castellano como recipiente y medio de difusión, proyectado de forma privilegiada hacia la historiografía indiana, de toda una compleja ideología legitimadora de la guerra de conquista contra los infieles y del desempeño del mando y el esfuerzo bélicos? Abordar de forma exhaustiva esta tarea a partir del análisis comparativo de narrativa historiográfica bajomedieval e indiana escapa, por la enjundia de esta tarea, al alcance y extensión de este artículo. Ahora bien, en la segunda parte de estas páginas, al menos, querría plantear la potencialidad de este presupuesto para su futuro desarrollo, entendiendo que tal aspecto ligado al campo de lo militar - con todas sus más amplias implicaciones ideológicas, geoestratégicas, sociales, económicas y culturales- no dejaría de formar parte de un todo histórico más complejo, que puede analizarse a partir de la concepción en términos sustancialmente continuistas de la civilización feudal del Occidente medieval, fundada cuando menos en los siglos plenomedievales, hacia el tiempo de la primera Modernidad y, más en particular, en el horizonte colonial de las Indias americanas ${ }^{17}$.

Es cierto que conviene ser cuidadosos a la hora de valorar continuidades, evoluciones y rupturas a la hora de comprender los procesos, muy a menudo violentos y que transformaron radicalmente tanto a los conquistadores como a los pueblos americanos originarios, de exploración, conquista, reorganización del territorio americano $y$, al fin, construcción de una nueva sociedad bajo el cuño hispano, prioritariamente castellano, más allá de la simple réplica de modelos previos o del surgimiento ex novo de la experiencia indiana ${ }^{18}$. Sin embargo, por lo que toca a la problemática de la escritura de la historia en la Castilla bajomedieval y en la monarquía de España de la Alta Edad Moderna, diversos autores han puesto ya de manifiesto la inserción también de los hechos de Indias y de la conquista americana en el propio desarrollo historiográfico, monarquista, nacionalista pero que también fue adquiriendo caracteres providencialistas, universalistas y humanistas, que va, cuando menos, de la Estoria de Espanna de Alfonso X a la Historia de España de Juan de Mariana ${ }^{19}$. Entiendo,

17 Un ejemplo reciente de esta postura en BASchet, La civilisation féodale, en particular pp. 380-416. No obstante, tales posicionamientos beben de una tradición historiográfica ya bien asentada, de la que pueden ser buenos ejemplos de su desarrollo a lo largo del siglo XX obras como la del belga VerLINDEN, The Beginnings, o la del mexicano WeCKMANn, La herencia medieval, entre otras, inclusive la de SÁNCHEZAlbornoz, La Edad Media española y la empresa de América. Algunas propuestas igualmente recientes y sugestivas sobre la necesidad de profundizar en esta línea de análisis histórico por lo que toca al problema de la conquista y colonización hispana de América en Ríos SAloma, "El mundo mediterráneo en la Edad Media"; IDEM, "La Edad Media Europea en perspectiva atlántica"; IDEM, "Dinámicas de conquista", además de un ejemplo de notable valor de su puesta en práctica desde una perspectiva crítica y actualizada en TORRó, "Partners-in-arms".

18 Sigue siendo fundamental remitir, por lo que toca a las distintas implicaciones socioculturales de ese espectacular choque sin opción de retorno operado entre europeos y amerindios, a las reflexiones de Serge Gruzinski y Carmen Bernard. Véanse, particularmente, BERnARD y GruZINSKi, De l'idolâtrie; GruZINSKI, La colonisation de l'imaginaire.

19 Véanse, cuando menos, además de los títulos citados en la nota 12, TATE, Ensayos sobre la historiografía peninsular; Fernández-Ordóñez (coord.), Alfonso X el Sabio y las Crónicas de España; Gómez Redondo, Historia de la prosa medieval castellana; CUART Moner, "La larga marcha hacia las historias 
pues, que contamos con una base más que coherente que justifica la propuesta de investigación que quiero plantear a partir del análisis comparativo de las referidas fuentes narrativas historiográficas.

\section{El rey de Castilla ante la guerra contra los musulmanes: "Restauraçión de Es- paña", cruzada y valores caballerescos ${ }^{20}$}

\subsection{El origen del modelo militar en la cronística de Alfonso XI}

Entonces, el punto de partida de este análisis ha de colocarse en el reinado de Alfonso XI (1312-1350). Esto no solo se debe al rotundo éxito de sus campañas contra los musulmanes, coronadas fundamentalmente con la victoria del Salado (1340) y la conquista de Algeciras (1344), resultado de ello el final de las intervenciones norteafricanas en la Península Ibérica, el control para los cristianos del estrecho de Gibraltar y el sometimiento efectivo al vasallaje de Granada respecto del rey de Castilla ${ }^{21}$. Las iniciativas de Alfonso XI fueron fundamentales a la hora de definir los principios que sustentarían la guerra contra los musulmanes hasta el final del siglo XV, dando lugar igualmente a un esfuerzo historiográfico de primer orden para fijar el discurso bélico frente al Islam propugnado por la monarquía, colocado al servicio de la superioridad de su poder ${ }^{22}$. No en vano, la Crónica de Alfonso Onceno y el Poema de Alfonso XI fueron las primeras obras donde el vocabulario de la cruzada se integró junto al de la "recuperación de España" en la justificación de la guerra contra los musulmanes en la Península Ibérica, con referencias claras a su consideración no solo como guerra justa y en servicio a Dios, la corona y la tierra del reino, sino también como "guerra santa" o "santa lid", "cruzada" o "romería". La inclusión de acciones con un claro valor simbólico, como el acto de la toma de la cruz por el rey antes de salir a campaña, la presencia del pendón de la Cruzada junto al del rey, el de Santiago o los pendones concejiles en ella o la fastuosa embajada remitida al papa Benedicto X en Avignon tras el triunfo del Salado son una buena muestra de esa integración de los valores cruzados,

de España en el siglo XVI; Kohut (ed.) Narración y reflexión; Courcelles, Escribir historia; Kagan, Los cronistas y la Corona; Gómez Redondo, Historia de la prosa de los Reyes Católicos; Léroy, L'historien et son roi. Para una actualización de esa inmersión de la temática indiana en el modelo historiográfico hispano construido a partir del modelo engendrado en torno a la cronística regia, Ríos SALOMA, "Una nueva historia para un mundo".

20 Remito especialmente a mi trabajo arriba citado (MuÑoz Gómez, "La construcción de un modelo de liderazgo militar"), donde se desarrolla de forma exhaustiva el análisis de ese modelo de liderazgo militar regio, los valores que lo caracterizaron y su presentación discursiva en los textos cronísticos. Por este motivo, estos mismos aspectos, tratados en el apartado 2 de ese artículo, aparecen aquí de forma más sintética para desarrollar la propuesta realizada acerca del trasvase de modelos sociales y narrativos del Medievo hispánico al contexto de Indias.

21 Manzano Rodríguez, La intervención de los Benimerines; Ladero Quesada, "La guerra del Estrecho"; Arias Guillén, Fernando, Guerra y fortalecimiento del poder regio en Castilla.

22 Para estos textos historiográficos, Crónica de Alfonso Onceno; Poema de Alfonso Onceno. 
a través de los cuales Alfonso XI se presentaba no solo como cabeza de su reino sino también como paladín de la Cristiandad en un momento de franca reafirmación de la ideología de cruzada en el Occidente latino ${ }^{23}$.

Ambos textos, por otro lado, otorgaban un papel de enorme relevancia al espíritu y los valores de la caballería en el desempeño del esfuerzo bélico del rey como ejemplo a sus vasallos. Sobre todo el Poema incidía en el esfuerzo de Alfonso XI y sus caballeros en un sentido más claramente épico y heroico, por la implicación directa en la cruzada del rey o por la invocación a reverdecer las hazañas y la fama ganadas por los monarcas antepasados de don Alfonso, hasta el mismo linaje de los godos, y por héroes como el propio Cid: la misma participación del monarca en un ethos caballeresco a imitar, pues. De un modo u otro, esta narrativa muestra cómo la guerra contra los musulmanes se convirtió en un elemento central del ideario monárquico de superioridad del poder real y restauración de la justicia en su reino, en el que la misión ancestral de la restauratio Hispaniae, la defensa cruzada de la Cristiandad y el liderazgo caballeresco iban de la mano, representados por Alfonso XI y a transmitir a la posteridad ${ }^{24}$. Esto no evitaba, en todo caso, que la actitud en la dirección de las operaciones de asedio y batalla campal por parte del rey que era reflejada en estos textos se articulara como un balance entre la implicación activa y arrojada en el combate, adecuada a la idea de la honra caballeresca, y una pragmática prudencia a la hora de evaluar riesgos y evitar posibles descalabros para los castellanos en situaciones de desventaja táctica o logística que amenazasen la seguridad y los intereses del rey y del reino ${ }^{25}$. Este thopos literario, también recogido en otras crónicas contemporáneas del siglo XIV, el cual oponía los deberes del caballero con la lógica de gobierno y mando militar correspondiente a un monarca, será reproducido de manera continua en contextos similares de guerra contra Granada en la cronística castellana posterior, obedeciendo a los dilemas de definición de las virtudes caballerescas y del mando que prioritariamente desarrolló la tratadística de re militari bajomedieval europea y castellana, tendiendo a reforzar progresivamente esa noción de la prudencia como valor positivo del caballero ${ }^{26}$. Cuando durante el reinado de su hijo Enrique II (1366/1369-1379) -otro reputado comandante militar, por otra parte- se elaborase la Gran Crónica de Alfonso XI, pese a que la consolidación de aquel en el trono y la justificación de sus derechos legítimos a él tras la derrota y asesinato de su hermanastro Pedro I alejaron a Castilla de cualquier iniciativa agresiva sobre Granada, era claro que el modelo de realeza pero también de caballero y caudillo contra el Islam esforzado y comprometido con esta misión que encarnara Alfonso XI se había constituido como un arquetipo a imitar para sus sucesores. Otro tanto podía decirse de la definición de la guerra contra Granada

\footnotetext{
23 Fernández Gallardo, "Guerra santa y cruzada"; Rodríguez-Picavea Matilla, "Diplomacia, propaganda y guerra santa"; Arias Guillén, "La imagen del monarca"; Nussbaum, Claves del entorno ideológico; Arias Guillén, "En Servicio de Dios e nuestro".

24 VAquero, El 'Poema de Alfonso XI'; Gómez Redondo, Historia de la prosa medieval castellana. II, pp. 1.265-1.266, 1.276-1.281; Fernández Gallardo, "Guerra santa y cruzada"; Nussbaum, Claves del entorno ideológico.

25 Arias Guillén, "Honor y guerra".

26 Rodríguez Velasco, El debate sobre la caballería.
} 
para la restauración de la España perdida por el visigodo Rodrigo como guerra santa y empresa caballeresca, aspectos que, de hecho, en la Gran Crónica eran formulados de forma mucho más explícita y clara ${ }^{27}$.

\subsection{El desarrollo del discurso en las crónicas castellanas regias del siglo XV}

Durante el siglo XV se observó el esfuerzo por parte de la monarquía castellana de retomar la guerra contra los musulmanes y revitalizar el discurso reivindicativo de este proyecto. Aunque los resultados militares globales durante los reinados de Juan II y Enrique IV pueden ser calificados como discretos, a razón de la discontinuidad de las pocas campañas organizadas por la Corona y del territorio conquistado a los granadinos, lo cierto es que las acciones militares comandadas directamente por los reyes y sus representates directos contra los musulmanes sí tuvieron una notable relevancia en la definición del discurso de ejercicio superior del poder regio y de este modo fueron bien reflejadas en la cronística de este siglo ${ }^{28}$.

Así, el infante Fernando 'el de Antequera', tío y regente de Juan II, entre 1407 y 1410, en su condición de más importante pariente regio, hizo del liderazgo en la guerra contra el Islam al servicio de la monarquía el eje central de legitimación de su propia autoridad en el reino. El recurso efectivo a la doble justificación de la restauratio Hispaniae y de la cruzada resultó notablemente enriquecido, mostrándose como un príncipe elegido por la Providencia y directamente protegido por la Virgen María para tal misión, vehiculando también los aspectos devocionales y caballeresco de tal esfuerzo a través de la orden de caballería por él fundada, de la Jarra y el Grifo. Además, en términos simbólicos, la exhibición en campaña de objetos como la espada Lobera, el pendón de San Isidoro de León o "de Baeza" o el de la cruzada, junto con el tradicional del Apóstol Santiago, permiten reconocer en tal representación simbólica el entronque con una herencia en esta línea recibida de los monarcas castellanos antepasados suyos, muy particularmente respecto de las personas y obras de Fernando III y Alfonso XI. Por otro lado, aunque el infante Fernando no contaba con experiencia militar previa al inicio de la campaña de 1407, su ejercicio del mando y la coordinación de abastecimiento, cabalgadas, asedios y batalla campal es globalmente elogiado en la Crónica de Juan II, reafirmando la imagen de prestigio militar que pretendía exhibir y que se vio coronada con la conquista de Antequera ${ }^{29}$. La exitosa implicación en la sucesión del trono de Aragón, lograda en 1412, detuvo la

\footnotetext{
27 Para su edición, Gran Crónica de Alfonso XI.

28 Para el seguimiento del conjunto de los conflictos entre Castilla y Granada a lo largo del siglo XV, Ladero Quesada, Las Guerras De Granada. Véanse también, para la regencia del infante Fernando en la minoría de edad de Juan II, GonzÁlez SÁnchez, Santiago, Los recursos militares de la monarquía; Muñoz Gómez, Fernando "el de Antequera", y para el reinado efectivo de Juan II y el de Enrique IV, Suárez Fernández, Juan II y la frontera de Granada; Porras Arboledas, Juan II; Martín, Enrique IV de Castilla; Echevarría Arsuaga, "Enrique IV de Castilla, un rey cruzado". Acerca de las treguas entre Granada y Castilla, Melo Carrasco, Las alianzas y negociaciones. Mientras, sobre la evolución política interna del reino de Granada durante el siglo XV, PELÁEz Rovira, El emirato nazari de Granada.

29 García de Santa María, Crónica de Juan II.
} 
continuación de cualquier acción ofensiva contra Granada, si bien la expectativa de su reanudación siguió siendo uno de los pilares en el control de la regencia en Castilla por parte de Fernando "el de Antequera" hasta su muerte en $1416^{30}$.

Aunque en buena medida ni Juan II ni Enrique IV reivindicaron explícitamente el modelo de liderazgo representado por el infante Fernando, a resultas de los conflictos civiles que los enfrentaron con los hijos de este, los infantes de Aragón, durante la primera mitad del siglo XV, esto no evitó que, en ambos casos, el discurso reactualizado en los años de regencia de aquel fuera recurrentemente manejado por los dos monarcas y que la voluntad teórica de culminar la conquista de Granada fuera un factor propagandístico relevante en ambos reinados. En el caso de Juan II, su implicación directa en campaña se limitó a una fugaz entrada en la frontera granadina en el verano de 1431, realizando en ella prácticamente sus primeras armas. El liderazgo de aquellas acciones culminadas en la batalla de la Higueruela correspondió prioritariamente a su privado, el condestable Álvaro de Luna. La delegación ritual del rey en el condestable que es transmitida por los distintos textos cronísticos que describen la campaña ${ }^{31}$, en todo caso, no impidieron a Juan II beneficiarse de su reconocimiento como rey cruzado, más allá del limitado alcance de estos episodios bélicos o del resultado conjunto de la política respecto a Granada en su reinado. No puede negarse, eso sí, que fue el condestable quien pudo arrogarse buena parte del prestigio ligado al liderazgo mesiánico, cruzado y caballeresco para el reino en ese objetivo justo y sacralizado de "recuperación de España" frente a los musulmanes, escenificando así su preeminencia en el orden político del reino ${ }^{32}$.

Mientras, por lo que respectó a Enrique IV, este no solo reunía, a su ascenso al trono en 1454, ya una cierta experiencia de combate, labrada a partir de 1439, sino que entre 1455 y 1458, en 1462 y 1464 encabezó diversas expediciones militares en la frontera granadina y se implicó en el sostenimiento de sus capitanes fronteros frente a los nazaríes. Aunque los relatos cronísticos referidos a su reinado se hallan profundamente divididos en la calificación del monarca a causa del contexto casi continuo de desorden y rebelión que se sucedió desde 1465 a su muerte en 1474 y por la problemática de la legitimación del acceso al trono de su hermanastra Isabel tras la posterior guerra de sucesión, lo cierto es que Enrique IV alcanzó un notable éxito al propiciar con su estrategia militar un sustancial avance de las posiciones castellanas fronterizas, con logros como las tomas de Archidona o Gibraltar. Más aún, el monarca y su entorno lograron también renovar la imagen del rey caballero cristiano y cruzado empeñado en la "recuperación

\footnotetext{
30 Muñoz Gómez, "De Medina del Campo a Zaragoza"; Idem, "La guerra contra el Islam en el proyecto político de Fernando «el de Antequera»"; IDEm, Fernando "el de Antequera", pp. 99-138.

31 Pérez de Guzmán, Fernán, Crónica del Señor Rey Don Juan; García de Santa María, Crónica de Juan II (CODOIN); Barrientos, Refundición; CARrillo de Huete, Crónica del halconero. Estos aspectos son particularmente evidentes en la propia obra cronística protagonizada por Álvaro de Luna (Crónica de don Álvaro de Luna, capítulos XXXIV-XXXIX).

32 Nieto Soria, "El ciclo ceremonial".
} 
de España”, preludiando en buena medida muchos de los elementos de este discurso que alcanzarían su culmen en el reinado de los Reyes Católicos ${ }^{33}$.

Es cierto que el proceder táctico de Enrique IV en campaña destacó por su prudencia, eludiendo la confrontación directa en campo abierto con los granadinos e insistiendo en las talas en su territorio con el fin de debilitar progresivamente su resistencia. Sin embargo, contrasta notablemente el relato de Alonso de Palencia y, en menor medida, de Diego de Valera, que insisten en la falta de arrojo e incluso en la cobardía de Enrique IV al implicarse solo en batidas de exploración de poco riesgo y dignidad para un caballero y un rey, pese a llegar a ser herido en una de estas escaramuzas ${ }^{34}$, del presentado por Diego Enríquez del Castillo, elogiando, junto a su participación en estas cabalgadas, el buen juicio del monarca y su preocupación por las vidas de sus hombres al evitar choques que pudieran ser desfavorables a las armas castellanas ${ }^{35}$.

De cualquier forma, el desenvolvimiento personal continuado de Enrique IV en la que era definida ya como bellum divinum, guerra divinal, una misión providencial de Castilla para con su historia y el destino de la Cristiandad frente a sus enemigos, no pudo dejar de ser reconocido por tratadistas como Alonso de Cartagena, Rodrigo Sánchez de Arévalo, el predicador Alonso de Espina o los cronistas que se ocuparon de su reinado desde posturas casi antagónicas, Diego Enríquez del Castillo y Alfonso de Palencia; autores estos en los que las influencias humanísticas en la comprensión y construcción del relato histórico son ya muy notables, por más que podamos retrotraerlas en Castilla al menos hasta la obra del canciller Ayala ${ }^{36}$. Fue, además, durante su reinado cuando por primera vez la culminación de las empresas granadinas del rey de Castilla fueron programáticamente conectadas con un fin ulterior de continuación de esa lucha de los cristianos contra los musulmanes del norte de África como vía alternativa para el acceso a la recuperación de Jerusalén, introduciendo este factor más de cruzada en el discurso monárquico castellano de la guerra contra los musulmanes. En efecto, la presentación de Enrique IV como paladín de la Cristiandad, respaldada por el papado, marcó un hito en una época de franco avance turco en el Mediterráneo oriental y los Balcanes, logrando la expedición de hasta diez bulas de Cruzada a su favor por parte del papa Calixto III, la concesión de la administración de las órdenes militares en sus reinos por diez años en 1456 o el simbólico galardón del estoque pontificio por dos veces, en 1458 y entre 1467 y $1469^{37}$.

\footnotetext{
33 Tinoco DíAz, La Cruzada en las fuentes cronísticas castellanas, pp. 255-276. Para una aproximación crítica al reinado de Enrique IV, Martín, Enrique IV, y, más en particular, a sus proyectos respecto a la frontera de Granada, SuÁrez Fernández, Juan II y la frontera de Granada, pp. 27-32; Echevarría Arsuaga, "Enrique IV de Castilla, un rey cruzado".

34 Ejemplos de ello en Palencia, Crónica de Enrique IV, vol. I, p. 72; Valera, Memorial de Diversas Hazañas, p. 22. En relación a las críticas de Alonso de Palencia y Diego de Valera al modo de guerrear de Enrique IV, Gómez Redondo, Historia de la prosa medieval castellana. IV, pp. 3.522-3.526.

35 Ejemplos en Enríquez del Castillo, Crónica de Enrique IV, pp. 20, 23.

36 En torno a la cronística del reinado, véanse al menos PaLencia, Crónica de Enrique IV, Crónica anónima de Enrique IV; Valera, Memorial de Diversas Hazañas; Enríquez del Castillo, Crónica de Enrique IV; Palencia, Gesta Hispaniensia.

37 Warmington, "The Ceremony of the Armed Man", pp. 123-128; Echevarría Arsuaga, "Enrique IV de Castilla, un rey cruzado", pp. 143-145, 148-152, 155-156.
} 


\subsection{La culminación del ideal restaurador y militar: la guerra de Granada, el proyecto monárquico de los Reyes Católicos y la figura del rey Fernando}

Al fin, fue durante el reinado de los Reyes Católicos que el discurso acerca de la guerra contra los infieles alcanzó, tanto desde el punto de vista restaurador como desde el de tipo cruzado, su forma más acabada y rica hasta aquel entonces pero también una apertura hacia un nuevo horizonte de proyección universal al que aspiró la monarquía de los reyes de Castilla y Aragón. No me extenderé aquí en los pormenores de la guerra de Granada ${ }^{38}$, centrándome en abordar la figura militar de Fernando el Católico y su puesta en relación con el programa monárquico marcadamente neogoticista en que se encuadró el conflicto desarrollado entre 1482 y 1492 hasta la última conquista de Granada ${ }^{39}$.

En este sentido, al rey Fernando correspondió el desempeño del liderazgo y el mando militar más efectivo frente al papel organizativo, de asistencia a la hueste y también en el plano piadoso y devocional asumido por la reina Isabel ${ }^{40}$. Este reparto de funciones entre los titulares de la monarquía se optimizó, a partir de la herencia discursiva, simbólica y representativa labrada desde, al menos, la época de Alfonso XI, al servicio de un ideal que no solo se dirigía hacia la expulsión de España de los invasores islámicos sino al propio restablecimiento de un orden hispánico común bajo los reyes de Castilla y Aragón. Sin duda, la conquista de Granada era comprendida en términos de recuperación (reintegratio Hispaniae), tanto en el relato historiográfico contemporáneo a los Reyes Católicos, como se aprecia en los textos de Alfonso de Palencia y Hernando del Pulgar, como en el discurso de la cancillería regia frente a poderes exteriores tanto cristianos como musulmanes. Pero ese proyecto más global integraba tal empresa en la consecución de la unidad cristiana de la monarquía de Fernando e Isabel, por un lado, y, por el otro, en el propio papel de los reyes hacia el conjunto de la Cristiandad, con su defensa frente a la amenaza islámica, reavivada tras la toma de Otranto de 1480, y el liderazgo de la cruzada que, programáticamente, habría de recuperar Jerusalén ${ }^{41}$. Fernando, en ese papel de caudillo militar, fue presentado como ejemplo de príncipe guerrero y gobernante, cuya figura venía precedida por una poderosa aura de mesianismo profético que hundía sus raíces en esa tradición catalano-aragonesa de naturaleza

\footnotetext{
38 Ladero Quesada, Castilla y la conquista del reino de Granada; Perez, Isabel y Fernando; Ladero Quesada, La guerra de Granada (1482-1491); Ribot GARCía, VALdeón BARUQue y MAZA Zorrilla (eds.), Isabel La Católica y su época, Ladero Quesada 2014.

39 Sobre la figura de Fernando el Católico es ineludible acudir a la obra de Belenguer Cebríà, Fernando el Católico. Para la ingente bibliografía generada en los últimos años y, más en particular, en relación con el centenario de su muerte, valga remitir a las referencias recogidas en Fernández de Córdova MiralLes, "El «otro príncipe»", pp. 15-19.

40 Fernández de Córdova Miralles, Álvaro, "El «otro príncipe»”, pp. 22; Tinoco Díaz, La Cruzada en las fuentes cronísticas castellanas, pp. 335-387, 421-438.

41 Peinado Santaella, “"Christo pelea por sus castellanos»”, y, en general, Peinado Santaella, Guerra santa, cruzada y yihad. Véanse igualmente FernÁndez de CóRdova Miralles, "El «otro príncipe»", pp. 19-31; Tinoco DíAz, La Cruzada en las fuentes cronísticas castellanas.
} 
escatológica desde finales del siglo XIII, ligada a la venida del rey que acabaría con el Islam, reconquistaría Jerusalén y reformaría la Iglesia, gobernando la Cristiandad en la unidad de la fe como el monarca universal que remite al emperador de los últimos días ${ }^{42}$. Dentro de este orden, en el ejercicio práctico de las armas, Fernando el Católico resultó el comandante más experimentado de todos los soberanos castellanos aquí analizados desde Alfonso XI. Había adquirido su primera experiencia de combate en 1465 en la guerra civil catalana y de mando desde 1475 en la guerra de sucesión al trono de Castilla, ampliándola y perfeccionándola sobre la base de reveses y triunfos a lo largo de ella, durante la guerra de Granada y aun en la campaña del Rosellón de $1503^{43}$. De este modo, alcanzó un enorme prestigio militar que combinó habitualmente la implicación audaz en acciones de combate de forma personal con las labores de coordinación y supervisión de las operaciones. El pulso entre estos dos perfiles del ethos caballeresco que venía definiéndose durante el final de la Edad Media, el del esfuerzo y el riesgo y el de la prudencia en el cálculo del riesgo al servicio de fines superiores, es bien reflejado en las narraciones tanto de Alonso de Palencia como de Diego de Valera y Fernando del Pulgar en acciones como los cercos de Vélez Málaga, Málaga o Baza $^{44}$. Pese a que el perfil de dirección táctica y estratégica por parte del rey Fernando fue adquiriendo progresivamente mayor protagonismo durante los años de la conquista de Granada ${ }^{45}$, ambas facetas aparecen celebradas en las crónicas, encarnando extraordinariamente como comandante las virtudes tanto de gobierno correspondientes al príncipe como las de capitán y, en conjunto, de caballero.

Cabe, entonces, recapitular que, en torno a Fernando el Católico durante la guerra de Granada cristalizó la forma más acabada de un discurso en que la noción de la restauratio Hispaniae, en su confluencia con los valores de la Cruzada y la defensa y expansión de la Cristiandad frente a sus enemigos durante la Edad Media, tardía aportó todo un cuerpo ideológico de liderazgo en tal esfuerzo de guerra de conquista. La cronística regia permite comprobar, como testimonio crucial en la definición y difusión del mismo, cómo, al menos desde Alfonso XI en la primera mitad del siglo XIV, tal noción de liderazgo fue bien representada por los reyes de Castilla como caudillos militares en torno a principios de servicio a Dios, a la Iglesia y al rey y al reino, esfuerzo y honra caballerescos y rememoración de la fama alcanzada por sus antepasados en pos de tales principios. Más aún, que no solo fue una de las bases de su propia legitimidad monárquica sino un modelo a seguir para los miembros del linaje regio, sus vasallos y súbditos en el servicio a la Corona y el ensalzamiento de su propia dignidad social. La resignificación de todo este aparato conceptual y discursivo durante el reinado de los Reyes Católicos, culminada la guerra de Granada y abiertas sus estrategias expansivas

\footnotetext{
42 Milhou, Alain, Colón y su mentalidad mesiánica; Aurell, "Messianisme royal de la Couronne d'Aragon"; Duran Grau y ReQuesens, Profecia i poder.

43 Mas Chao, "La formación militar del Rey Católico".

44 Pulgar, Crónica de los Reyes Católicos, pp. 266-267; Valera, Crónica de los Reyes Católicos, p. 275; Palencia, Guerra de Granada, p. 404.

45 Tinoco DíAz, La Cruzada en las fuentes cronísticas castellanas, pp. 414-415, 421-438.
} 
en los escenarios mediterráneo-italiano y atlántico, llevarían a enlazar esta noción de la guerra contra los musulmanes y su liderazgo con una suerte de teórica comunidad de intereses en torno a la idea de monarquía cristiana universal respaldada por el papa. La misma, de una parte, reconocía a los monarcas españoles, y particularmente a Fernando el Católico, como su campeón, salvador de Italia y defensor del Orbe frente a los enemigos infieles - pero también cristianos que no aceptasen la autoridad temporal papal-y, de otra parte, sancionaba las expediciones castellanas hacia las Indias en tanto forma de expansión de la Cristiandad mediante la evangelización de sus pobladores ${ }^{46}$. De este modo, el sustrato ideológico monárquico de la guerra hispánica contra los musulmanes durante la Baja Edad Media, eminentemente castellano pero reactualizado a partir de influencias catalano-aragonesas y suritálicas, alcanzado el que parecía su culmen en el espacio peninsular ibérico, se proyectaba hacia un nuevo horizonte abierto al Mediterráneo y al Atlántico que acabaría heredando el emperador Carlos y la casa de Austria.

\section{Crónicas bajomedievales y “crónicas de Indias”: ¿una relación posible?}

Aunque los derechos de los reyes de España sobre las Indias tuvieran más que ver con la legitimidad reconocida al dominio de aquellas tierras de cara la evangelización de sus pobladores nativos a partir de las bulas del papa Alejandro VI que con el fantástico -e interesado- descubrimiento de las Antillas por el hispano Hespero esgrimido por Gonzalo Fernández de Oviedo, lo cierto es que, a juzgar por el punto de vista de este autor, la idea de continuidad del ideal conquistador hispánico en los confines del Occidente latino de origen medieval sí parecía mostrar un notable vigor en las primeras décadas del siglo XVI. Hasta este punto he pretendido mostrar cómo, efectivamente, la noción de la restauratio Hispaniae, en su confluencia con los valores de la Cruzada y la defensa y expansión de la Cristiandad frente a sus enemigos y los pueblos gentiles en la Edad Media tardía, aportó una doctrina de liderazgo en tal esfuerzo de guerra de conquista que, enriquecida progresivamente, se hallaba bien vigente entre finales del siglo XV y los inicios del siglo XVI, al inicio de la exploración y conquista americana.

Así, la historiografía regia castellana de los siglos XIV y XV adquirió un enorme protagonismo en la fijación y transmisión social de dichas nociones, del discurso propagandístico y del lenguaje simbólico a ellas asociados. Más aún, las crónicas también contribuyeron a la expresión de un poderoso modelo de virtud militar y ejercicio del mando encarnado por los reyes y, en general, por la monarquía y sus agentes, que bebía directamente de los ideales aristocráticos de la caballería de su época, sin dejar de ser ajenas a las influencias humanísticas en la construcción del relato histórico. Incluso, la tensión contradictoria entre el arrojo en el combate que se requería al caballero y las llamadas a la prudencia en el liderazgo militar que se demandaba al comandante que se ha podido observar en la cronística no era sino un reflejo del mismo debate que en este sentido se aprecia en los

46 Fernández de Córdova Miralles, "El «Rey Católico» de las primeras Guerras de Italia”; Idem, "El «otro príncipe»", pp. 19-31. 
tratados de re militari latinos y en lengua vernácula que fueron producidos o traducidos en Castilla durante estos siglos. Justamente, esta tratadística - que participaba al menos en parte de la relectura e interpretación de ejemplos clásicos, además de las interpretaciones de origen tomista sobre la cuestión de la caballería - tendió a subrayar la primacía de la prudencia como una virtud caballeresca, sinónimo de la sabiduría y el conocimiento de la táctica y la estrategia militar que había de corresponder a todo buen capitán, frente a las consecuencias nefastas que podía acarrear la temeridad y falta de planificación en la implicación en el combate ${ }^{47}$. A razón de todo esto, cabe entonces preguntarse si, en efecto, como proponía inicialmente, el ejemplo de las cualidades militares y de mando que se ha rastreado a partir de la historiografía real castellana de los siglos XIV y XV puede sondearse de algún modo en las fuentes disponibles como un espejo para los capitanes que protagonizaron las empresas de conquista en el Nuevo Mundo.

Como se planteaba inicialmente, comprender la posible influencia de ese género cronístico bajomedieval en la narrativa de las "crónicas de Indias" en torno a ese ejercicio del mando y el oficio de las armas resulta una cuestión de máxima relevancia para este fin. Cuando menos, tratar de reconocer los elementos del discurso historiográfico bajomedieval trasvasados a los textos indianos, las posibles evoluciones o irrupciones de elementos novedosos en torno a la cuestión que nos ocupa debería ayudar a precisar mejor la influencia de la tradición cultural bajomedieval castellana en el horizonte mental de la América de la exploración y la conquista del siglo XVI alrededor de esa cuestión del liderazgo militar. En cualquier caso, el acceso al estado actual de la investigación al respecto arroja un balance discreto en lo tocante a la atención prestada a los posibles vínculos entre ambas historiografías.

Así, ha de partirse de que los diferentes textos narrativos elaborados entre el siglo XVI y las primeras décadas del siglo XVII e incluso durante el siglo XVIII que han sido catalogados bajo el epíteto de "crónicas de Indias" responden formalmente a una tipología diversa en la que, por otro lado, es difícil establecer claras distinciones entre los textos a los que se reconoce un carácter claramente literario y aquellos otros en los que este no es fácilmente detectable o se niega frente a su condición fundamentalmente documental. Más todavía, José Carlos González Boixo advertía sobre el valor historiográfico de no pocos poemas épicos y de su posible consideración dentro de estos textos, amén de lo mucho que queda por hacer a la hora de valorar tanto las posibles relaciones de esa narrativa indiana con la tradición historiográfica antigua, medieval y renacentista contemporánea, con la narrativa de ficción y la posibilidad de que la cronística de Indias terminara generando un modelo propio ${ }^{48}$.

\footnotetext{
47 Gómez Moreno, "La militia clásica y la caballería militar"; Rodríguez Velasco, El debate sobre la caballería, pp. 317-343; FernÁndez Gallardo, "Alonso de Cartagena y el debate sobre la caballería". Un ejemplo entre la tensión en la evolución del discurso letrado sobre el tema y su contradictoria integración y aplicación en el campo de batalla en la Castilla del siglo XV en CAstillo CÁceres, "La caballería y la idea de la guerra".

48 GonzÁlez Boixo, "Hacia una definición de las crónicas de Indias". No entraré en la problemática consideración literaria de las "crónicas de Indias", si bien conviene revisar trabajos como los de PUPO WALKer, La vocación literaria; GonzÁlez EchevarríA, "Humanismo, retórica”; o AÑón y BATTCOCK, "Las
} 
Walter Mignolo venía a diferenciar, en su intento de clasificación de estos textos, entre las "cartas relatorias" (cartas que narran acontecimientos y/o describen los espacios y poblaciones americanos), las "relaciones de la conquista" (informes generados por los oficiales de la monarquía española en América sobre estas mismas cuestiones) y propiamente las "crónicas" o "historias" (textos narrativos con pretensiones y forma historiográficas), ligando estas a los modelos historiográficos generales vigentes en los siglos modernos ${ }^{49}$. Mientras, de la edición de una antología de esas "crónicas de Indias" de Mercedes Serna pueden extraerse tres aspectos característicos de estos textos. Por un lado, la relevancia de los materiales propios de lo maravilloso y lo fantástico en la construcción de la narración de ese nuevo universo americano, eje en buena medida de su análisis de estos relatos a caballo entre la realidad y el mito ${ }^{50}$. Por otro lado, la vinculación de esas imágenes, casi precursoras de un estilo narrativo tendente, a su juicio, al "realismo mágico", con materiales historiográficos, geográficos, mitológicos y literarios fundamentalmente antiguos, más allá de las referencias puntuales a su transferencia a la cultura de las gentes del siglo XVI a través de los tiempos medievales o incluso a textos medievales que nutrían esta mirabilia, como Los Viajes de Marco Polo o el Imago Mundi de Pierre d'Ailly ${ }^{51}$. Finalmente, la consideración fundamentalmente moderna, propia del contexto renacentista y condicionada por esa especificidad del Nuevo Mundo americano, del relato indiano. Pese a que no se elude que la tradición historiográfica medieval castellana condicionó vivamente el sentido de la cronística americana - providencialismo, "nacionalismo", expansionismo, moralismo - aun integrando influencias humanísticas, su peso parece ser considerado menor frente a otros influjos, sobre todo los de carácter clásico y humanístico, otorgando también no poca relevancia al papel de la literatura de caballerías en la configuración del universo mental de los autores indianos ${ }^{52}$.

Este último aspecto entronca con el conocido trabajo de Irving Leonard sobre ese acervo literario de los conquistadores, en el cual el libro de caballerías ha sido subrayado como un material de primer orden en la configuración de la moralidad y la conducta de estos personajes llegados a América desde el final del siglo XV, ligada a la incitación a la hazaña y la consecución de la fama y la gloria ${ }^{53}$. Más allá de la confusión y la dificultad en el propio análisis como género único y diferenciado de las llamadas "crónicas de Indias"

\footnotetext{
crónicas coloniales", junto al dossier por estas últimas autoras coordinado en dicha revista con el título Las crónicas coloniales desde América: aproximaciones y nuevos enfoques.

49 Mignolo, "Cartas, crónicas y relaciones", pp. 57-117, en concreto pp. 75-98,103-110. Habría que añadir al menos también las "relaciones particulares", según González Boixo, que parecen aludir a informes sobre temas históricos, geográficos, etnográficos, etc. redactados por individuos no vinculados al aparato de gobierno de la Corona y que no estaban destinados a servir como fuente de información para ella (GonZÁlez Boixo, "Hacia una definición de las crónicas de Indias", p. 236).

50 Serna (ed.), Crónicas de Indias. Antología, pp. 13-102.

$51 \quad$ Ibidem, pp. 32-33.

$52 \quad$ Ibidem, pp. 60-69.

53 Leonard, Books of the Brave, II The Romances of Chivalry. Partiendo de esta base pero atendiendo a referencias literarias y, en general, culturales más diversas, en relación con la conquista de México, Turner, Los soldados de la Conquista, en concreto pp. 16 y ss.
} 
o incluso de la consideración literaria de muchos de estos textos, lo que aquí interesa es incidir sobre lo poco que se ha profundizado en la búsqueda de conexiones entre ellas y sus posibles referentes literarios medievales, muy particularmente aquellos de tipo cronístico pese a la voluntad en mayor o menor medida historiográfica de esos textos narrativos de materia americana. En caso, parecen haber sido considerados, entre las influencias literarias de más peso en esta narrativa de Indias, los referentes de ficción y muy particularmente aquellos generados en ese tránsito entre la Edad Media y la Modernidad, entre los cuales cabe incluir también las ya citadas influencias de las revisitaciones de mitos clásicos y cristianos, de las descripciones y relaciones geográficas y de viaje que abundan en "lo maravilloso" y del libro de caballerías, además de las procedentes del romancero o de modelos épicos como los del Cid o el Bernardo del Carpio reinterpretados en sus versiones impresas del final del siglo XV y del siglo XV o de la lírica renacentista ${ }^{54}$.

Así, volviendo a Gonzalo Fernández de Oviedo, las características de muchos de los infanzones, hidalgos y caballeros que desfilan por su Historia Natural y General de las Indias (honor, valor, audacia, coraje, esfuerzo, fidelidad al rey y rebeldía hacia sus superiores directos $\mathrm{y}$, en principio, legítimos) han sido interpretadas a través de este tamiz literario, integrándose a lo "verdadero" de su relato una descripción del horizonte geográfico y humano de las Indias teñido por lo "maravilloso", vicaria igualmente de dichas referencias ${ }^{55}$. Acaso, tal imagen no pretendía sino representar un modelo ideal del líder conquistador de acuerdo con los valores aristocráticos y caballerescos admirados por Fernández de Oviedo, sin eludir la crítica a las acciones más brutales contra los indios perpetradas por los capitanes castellanos y del alejamiento por parte de estos de la práctica de tales principios de caballería y nobleza ${ }^{56}$. Todo ello por más que también el mesianismo y el providencialismo histórico en torno a la misión que correspondía a Castilla y los castellanos en la empresa americana como parte de esa monarquía universal se hallaran bien insertos en el proyecto historiográfico de este autor, como ya señalara Edmundo O'Gorman ${ }^{57}$. Por otra parte, tomando el ejemplo de la construcción de la imagen de Hernán Cortés por parte de Fernández de Oviedo, se evidencia de manera si cabe más palmaria el complejo pulso entre el afán de verdad en la elaboración del relato histórico a partir de ingentes testimonios documentales, informaciones escritas y orales y el recurso a la experiencia propia, por un lado, y el peso de los objetivos ideológicos y legitimadores últimos que pesaban en la escritura del autor. De este modo, entre los intereses de los conquistadores y la superioridad de la Corona, la acción de Cortés en las tierras de la posteriormente conocida como Nueva España que nos plantea Fernández de Oviedo no se halla exenta de ambigüedades. El conquistador de México-Tenochtitlan

\footnotetext{
54 Antelo Iglesias, "De lo medieval y lo renacentista".

55 Coello de la Rosa, "El héroe cidiano"; Idem, "Historias naturales y colonialismo", pp. 47-53; IdEM, Historia y ficción. La escritura de la Historia general y natural de las Indias.

56 Bolaños CÁrdenas, "La crónica de Indias de Fernández de Oviedo"; Bénat-Tachot, "Figura y configuración de "enemigo americano"”.

57 O’Gorman, Cuatro historiadores de Indias, pp. 64-70. Véase igualmente Pérez DE Tudela y Bueso, "Estudio preliminar", como estudio clásico de base para el análisis historiográfico de la obra de Fernández de Oviedo.
} 
es, pues, objeto de admiración y crítica: son ensalzadas sus virtudes como comandante victorioso que respondía a las virtudes del valor, el esfuerzo, la cautela y la habilidad del mando, además de su servicio al rey, pero también señalando sus acciones brutales y desleales, tanto contra las poblaciones mesoamericanas como contra los agentes de la monarquía española y, en último término, el propio rey, contrarias al ethos caballeresco y del liderazgo propuesto por nuestro autor. De este modo, en fin, Cortés no deja de aparecer en el discurso sobre la conquista trenzado por Fernández de Oviedo en un lugar de mérito pero también de denuncia, de donde no podía escapar ni podía dejar de supeditarse al proyecto liderado por la Corona $^{58}$.

En todo caso, la exploración de las conexiones de la producción historiográfica indiana, al menos la más temprana, con la tradición cronística bajomedieval sigue siendo a día de hoy una tarea en buena medida por hacer. No obstante, algunas voces han llamado la atención sobre la evolución de los procedimientos narrativos y las estrategias en la organización de los textos de la cronística medieval castellana y su influjo en los relatos historiográficos de Indias. De este modo, no hace muchos años, Leonardo Funes animaba a continuar el estudio de estos aspectos a partir de un repaso de las cuestiones temáticas del relato histórico proyectado, del papel asumido por el narrador en el mismo o de los recursos integrados en la narración cronística, desde los referentes latinos de la cronística alto y plenomedieval hasta la consolidación del ciclo cronístico regio castellano con Pero López de Ayala y la posterior multiplicación durante el siglo XV de las narraciones de contenido historiográfico en prosa. La progresión desde la concepción universalista de la narración histórica hacia discursos vinculados al conjunto de España como "ente supranacional" y al reino, la monarquía, el linaje o la comunidad, la mayor sofisticación adquirida en la búsqueda de equilibrio entre el objetivo ideológico perseguido en la crónica y el afán de objetividad y neutralidad en la relación de los hechos acontecidos por parte del narrador, la propia adquisición de protagonismo de este como yo enunciador en primera persona y copartícipe del relato tanto en la crónica real como en la de tipo particular, en la biografía caballeresca y el relato de viajes desde finales del siglo XIV o la multiplicación de recursos narrativos del más diverso origen manejados en su elaboración (el exemplum o el plactus, relatos hagiográficos, milagros marianos, visiones oníricas, material de tipo genealógico, léxico político, del registro jurídico de la feudalidad o notarial, etc.) ayudan a comprender mejor los productos historiográficos generados por Fernández de Oviedo o Bernal Díaz del Castillo como partícipes de una larga evolución del género historiográfico castellano ${ }^{59}$.

Tales ideas - maduradas dentro del entorno de trabajo acerca a la cronística castellana fraguado alrededor del maestro de Funes, Germán Orduna- confluyen con planteamientos ya antes expuestos por otros autores, como en el caso de James Ray Green Jr. por lo que toca al origen medieval de gran número de recursos estilísticos locali-

\footnotetext{
58 BÉnAt-TAchot, "Gonzalo Fernández de Oviedo y la gesta de los "cortesanos"”.

59 FunEs, "De la crónica medieval a la crónica de Indias".
} 
zados, en este caso, en la obra de Díaz del Castillo ${ }^{60}$. A su vez, partiendo del estudio del Frida Weber de Kurlat sobre la estructura del Amadis de Gaula ${ }^{61}$, se constataba cómo podía rastrearse tanto en la novela de caballerías como antes en la cronística el manejo de fórmulas presentes en la Historia verdadera de la conquista de la Nueva España, como son los nexos internos como recurso para entrelazar y dotar de continuidad al relato («Dejemos a Botello, que después tornaré a hablar de él y diré cómo se dio luego orden que...», «Pasemos adelante y diré como...», «Y volvamos a decir cómo llegamos aquél día...») o el manejo de formas de amplificación retórica como las prolijas descripciones de escenas y los largos diálogos para otorgar veracidad a la información presentada y verosimilitud a la narración, remitiendo la autora al estudio de las Generaciones y Semblanzas de Fernán Pérez de Guzmán realizado por Francisco López Estrada ${ }^{62}$.

Por tanto, es posible afirmar que, pese a las dificultades a afrontar, existe un campo abierto a la exploración de una relación real entre la narrativa historiográfica bajomedieval castellana y las “crónicas de Indias". Ciertamente, estos vínculos se establecieron dentro de un contexto literario durante los siglos XV y XVI de intensa intertextualidad entre obras de géneros muy diferentes, tanto líricas como en prosa, y que participaban en diverso grado de la pervivencia de modelos medievales o de las distintas influencias de tipo humanístico, tanto en la literatura de ficción como en la prosa historiográfica, en el cual ha de ser analizado convenientemente el peso del género cronístico castellano heredado desde, al menos, el siglo XIV. En cualquier caso, como vengo defendiendo, parece claro que muchos de los valores militares y sociales de los que participaron los capitanes y gente de armas de las expediciones de exploración y conquista en Indias como la búsqueda de la fama y el honor, el valor, la audacia, la prudencia, la fidelidad al rey y a la patria, el servicio a Dios y a una causa justa -cuando no sacralizada- no solo se pueden localizar en esa literatura de ficción del tránsito entre la Edad Media y la Edad Moderna sino también en la cronística.

\section{Conclusiones}

En fin, a resultas de lo aquí planteado, creo que se puede concluir que el género cronístico bajomedieval castellano sí sirvió, efectivamente, como recipiente y medio de difusión de primer orden de la ideología restauradora y cruzada que legitimaba la guerra contra los musulmanes liderada por la monarquía. Del mismo modo, recogió

\footnotetext{
60 GREEN JR., "La retórica y la crónica de Indias".

61 Weber de Kurlat, "Estructura novelesca del Amadis de Gaula".

62 López Estrada, "La retórica en las Generaciones y semblanzas". Resulta de interés, acerca del papel de la retórica en la narración cronística de la conquista de México de Francisco López de Gómara, Bernal Díaz del Castillo y fray Juan de Torquemada, la monografía al respecto de Alfonso Mendiola Mejía, si bien la búsqueda de antecedentes medievales se halla más concentrada en la exégesis bíblica latina que en referentes en lengua romance castellana (Mendiola Mejía, Retórica, comunicación y realidad, pp. 383-394).
} 
la redefinición de dichos principios con el final de la guerra de Granada dentro de un proyecto político que superaba los límites ibéricos, a caballo entre el Viejo y el Nuevo Mundo, y se enunciaba en términos de universalidad, volcado en la defensa y expansión de la Cristiandad por esa monarquía de España. Del mismo modo, la historiografía real de los siglos XIV y XV contribuyó a definir y diseminar un modelo de cualidades militares y de mando de hondo sentido caballeresco, que en el caso castellano alcanzaba su mejor expresión escenificado por el rey e imitado por sus vasallos en torno a las empresas de guerra contra los musulmanes. El trasvase de tales valores guerreros a los contextos de la conquista americana puede vislumbrarse a través de su reproducción y adaptación en las "crónicas de Indias", a partir de diferentes fuentes textuales, partícipes de un acervo cultural común, habiendo podido tratar aquí con mayor particularidad estos hechos en el caso de la Historia Natural y General de las Indias de Gonzalo Fernández de Oviedo.

Robert Bartlett señaló a principios de los años 90 del siglo XX cómo una de las claves de la expansión del Occidente latino durante la Edad Media había sido su capacidad para reproducir modelos de unidades sociales básicas institucionalmente organizadas en los nuevos territorios ocupados ${ }^{63}$. Algunos años antes, Charles Verlinden sugirió que los procesos de colonización americanos se basaron de forma importante en la implantación de un modelo fraguado en Italia y la península ibérica de comunidades humanas de tipo urbano, institucionalizadas y ligadas a la presencia de asociaciones militares que garantizaban el control y la explotación del territorio ${ }^{64}$. Muy recientemente, como ya señalaba anteriormente, Josep Torró ha conectado agudamente ambas interpretaciones a la hora de establecer una confluencia entre las formas de apropiación del espacio y la autonomía institucional y militar ligadas a los concejos de la frontera cristiana ibérica frente al-Andalus desde los siglos XI y XII hasta el final del siglo XV y la adaptación de los modelos medievales hispanos de entrada y cabalgada, asociación militar en huestes y ocupación y organización del espacio mediante la fundación de ciudades y el repartimiento del espacio y los recursos entre los conquistadores en América desde $1492^{65}$. Entonces, la comprensión de tales procesos complejos, cruentos muy a menudo, obliga a profundizar también en el universo mental de esos conquistadores y en el efecto provocado por su llegada en la transformación de las sociedades americanas originarias. No puede ser de otro modo si se pretende acceder a un más aquilatado conocimiento de las motivaciones para la implantación de aquellos contingentes humanos en el Nuevo Mundo, los conceptos, organizaciones y fórmulas que conformaron el desarrollo en Indias de una nueva sociedad inserta en el orbe hispánico de la temprana Modernidad y las identidades sociales que se generaron en estos territorios como un fruto complejo del propio bagaje histórico de raíz medieval y de las circunstancias contemporáneas que afrontaron esos conquistadores y colonos, tanto propias como ligadas al contacto

\footnotetext{
BARTLETT, The Making of Europe, pp. 111-132, 306-314.

4 Verlinden, The Beginnings of the Modern Colonization, pp. 3-32.

65 Torró, "Partners-in-arms. Medieval Military Associations".
} 
impactante y a menudo virulento con el "otro" americano: el territorio y las sociedades que lo poblaban y organizaban antes de la llegada de los españoles ${ }^{66}$.

En este sentido, entiendo que estas páginas puedan contribuir, además de para sistematizar el aparato conceptual y simbólico articulado en la Castilla bajomedieval en torno al liderazgo en la guerra contra los musulmanes, como aportación útil a la hora de comprender mejor la mentalidad compartida por los miembros de las huestes indianas y sus jefes. Un análisis más profundo de este modelo conceptual militar que he trazado en la cronística castellana bajomedieval y de la lógica social a la que respondía, participada desde la gran aristocracia del reino hasta la caballería concejil o incluso el común de las áreas de la frontera andaluza, y de su trasvase posterior a América ineludiblemente ha de pasar por su contraste en otras fuentes narrativas medievales que permitan aproximarnos a las prácticas y valores de la caballería y del combate contra los enemigos islámicos, además de las indianas, por supuesto, para la confrontación con las sociedades autóctonas. Es el caso, afortunadamente, de los ejemplos que pueden extraerse de la crónica particular del siglo XV, como los aportados por El Victorial, la ya citada Crónica de Don Álvaro de Luna, los Hechos del condestable don Miguel Lucas de Iranzo o la Historia de los hechos del marqués de Cádiz $z^{67}$. También de los correspondientes a otros textos de contenido explícita o implícitamente historiográfico que refieren las características de la guerra fronteriza contra los musulmanes a finales de esta misma centuria y el comportamiento de los capitanes cristianos y sus compañeros tanto por tierra, como en el caso del Cronicón de Benito de Cárdenas, para el área jerezana, como por mar, en el caso del Memorial de la guerra de allende, redactado en $1505^{68}$.

Del mismo modo, entiendo igualmente que el reconocimiento más preciso de esa "herencia medieval" de la conquista puede ser de notable interés a la hora de comprender mejor la percepción que desde las sociedades amerindias se hizo de la llegada de los españoles, de sus formas de hacer la guerra y del efecto que supuso para ellas la imposición hispana. Estos aspectos son igualmente rastreables a partir de los productos historiográficos generados por autores indígenas o a partir de la memoria y tradición -al menos parcial- de los pueblos amerindios dominados en las décadas posteriores a aquellos acontecimientos de conquista hispana, por más que cualquier lectura de las mismas haya de tener en cuenta la impronta occidental y cristiana que afectó a tales procesos de producción y transmisión de conocimiento histórico

\footnotetext{
66 Sigue siendo de referencia como punto de partida para un trabajo de estas características el estudio social de Bernard Grunberg sobre los conquistadores en la Nueva España. A tenor de lo expuesto, los ideales de servicio a Dios y al rey y de búsqueda de riqueza, honra y gloria, señalados por el autor francés entre los motores ideológicos que alimentaban a los expedicionarios de la conquista (GRUNBERG, L'univers des conquistadores, pp. 51- 79), bien merecen una revisitación en torno a su construcción conceptual desde tiempos medievales y su integración en los procesos de contacto e imposición de los españoles sobre las poblaciones nativas americanas.

67 Crónica de don Álvaro de Luna; Hechos del condestable don Miguel Lucas de Iranzo; Historia de los hechos del marqués de Cádiz; Díaz de GAmes, El Victorial.

68 JimÉnez de la EsPADA, "La guerra del moro a fines del siglo XV"; Cronicón de Benito de Cárdenas.
} 
protagonizados por indios y mestizos ya bajo la égida española ${ }^{69}$. En cualquier caso, creo que estamos ante una vía de extraordinaria riqueza aún por explotar a la hora de conocer mejor la transmisión, redefinición y generación de prácticas, conceptos, instituciones y modelos, sin duda literarios y discursivos pero también socio-políticas, económicas y culturales a caballo entre el Medievo y la Modernidad entre ambas orillas del hemisferio atlántico hispano.

\section{Bibliografía}

\subsection{Fuentes cronísticas}

Crónica anónima de Enrique IV de Castilla, 1454-1474: crónica castellana, ed. Mª P. Sánchez Parra, Ediciones de la Torre, Madrid, 1991.

Crónica de Alfonso Onceno, ed. Francisco Cerdá y Rico, Imprenta de Don Antonio de Sancha, Madrid, 1787.

Crónica de don Álvaro de Luna, condestable de Castilla, maestre de Santiago, ed. Juan de Mata Carriazo, Espasa Calpe, Madrid, 1940.

Cronicón de Benito de Cárdenas. Jerez y la frontera castellano-granadina (1471-1483), ed. Juan Abellán Pérez, Peripecias Libros, Jerez de la Frontera, 2014.

Gran Crónica de Alfonso XI, ed. Diego Catalán, Gredos, Madrid, 1976.

Hechos del condestable don Miguel Lucas de Iranzo, ed. Juan de Mata Carriazo, Espasa Calpe, Madrid, 1940.

Historia de los hechos del marqués de Cádiz, ed. Juan Luis Carriazo Rubio, Universidad de Granada, Granada, 2003.

Poema de Alfonso Onceno, ed. Juan Victorio, Cátedra, Madrid, 1991.

Barrientos, Lope de, Refundición de la Crónica del Halconero, ed. Juan de Mata Carriazo, Real Academia de la Historia, Madrid, 1946.

CARrillo de Huete, Pedro, Crónica del halconero de Juan II, ed. Juan de Mata Carriazo, estudio preliminar Rafael Beltrán, Universidad de Granada, Granada, 2006.

Díaz de GAMEs, Gutierre, El Victorial, ed., estudio y notas Rafael Beltrán, Real Academia Española-Galaxia Gutenberg. Círculo de Lectores, Madrid-Barcelona, 2014.

EnRíquez del Castillo, Diego, Crónica de Enrique IV, ed. Aurelio Sánchez Martín, Universidad de Valladolid, Valladolid, 1994.

\footnotetext{
69 Baste citar, sin salir del ámbito novohispano y mexicano, por un lado, la obra clásica en este sentido de León Portilla, Visión de los vencidos, clave por lo que respecta a la exploración y análisis de este tipo de historiografía, y un ejemplo aún reciente del desarrollo y enriquecimiento teórico, metodológico y analítico de esta línea de trabajo con el libro de Pastrana Flores, Historias de la conquista.
} 
García de SAnta MaríA, Álvar, Crónica de Juan II (Colección de Documentos Inéditos para la Historia de España, Vols. 99 y 100), ed. Antonio Paz y Meliá, Real Academia de la Historia, Madrid, 1891.

García de Santa María, Álvar, Crónica de Juan II, ed. Juan de Mata Carriazo Real Academia de la Historia, Madrid, 1982.

FERnÁNDEZ De Oviedo, Gonzalo (1851-1855): Historia General y Natural de las Indias, Islas y Tierra-Firme del Mar Océano, ed. José Amador de los Ríos, Real Academia de la Historia, Madrid, 1851-1855.

JiMÉNEZ DE LA EsPADA, Marcos, "La guerra del moro a fines del siglo XV", Boletín de la Real Academia de la Historia, 25 (1894), pp. 171-212.

Palencia, Alfonso de, Crónica de Enrique IV, ed. y traducción al castellano, Antonio Paz y Meliá, Tipografía de la Revista de Archivos, Madrid, 1904-1908.

Palencia, Alfonso de, Guerra de Granada, ed. Antonio Paz y Meliá, estudio e índices Rafael G. Peinado Santaella y Amparo González Ferrer, Universidad de Granada, Granada, 1998.

Palencia, Alfonso de, Gesta Hispaniensia ex annalibus suorum dierum collecta, ed., estudio y notas Robert B. Tate yJeremy Lawrence, Real Academia de la Historia, Madrid, 1998-1999.

Pérez de GuzMÁn, Fernán, Crónica del Señor Rey Don Juan, segundo de este nombre en Castilla y en León, ed. Lorenzo Galíndez de Carvajal, Imprenta de Benito Monfort, Madrid, 1779.

Pulgar, Fernando del, Crónica de los Reyes Católicos, ed. Juan de Mata Carriazo, estudio preliminar Gonzalo Pontón, Universidad de Granada, Granada, 2008.

Valera, Diego de, Crónica de los Reyes Católicos, ed. Juan de Mata Carriazo, Anejos de la Revista de Filología Española, Madrid, 1927.

Valera, Diego de Memorial de Diversas Hazañas. Crónica de Enrique IV, ed. Juan de Mata Carriazo, Espasa Calpe, Madrid, 1941.

\subsection{Estudios}

Antelo Iglesias, Antonio, "De lo medieval y lo renacentista en las letras hispanoamericanas del siglo XVI”, Epos: Revista de filología, 5, (1989), pp. 295-326.

AÑón, Valeria, y BATTCOCK, Clementina, "Las crónicas coloniales desde América: aproximaciones y nuevos enfoques", Latinoamérica. Revista de Estudios Latinoamericanos, 57 (2013), pp. 153-159.

Arias Guillén, Fernando, "Honor y guerra. La tensión entre la realidad bélica y el discurso ideológico en la cronística castellana de la primera mitad del siglo XIV", Hispania. Revista española de Historia, 232 (2009), pp. 307-330. 
Arias Guillén, Fernando, "La imagen del monarca en el siglo XIV. Alfonso XI frente a Eduardo III", e-Spania, 11 (2011), < https://journals.openedition.org/e-spania/20412 $>$ (12-12-2018).

Arias GuILLÉN, Fernando, Guerra y fortalecimiento del poder regio en Castilla. El reinado de Alfonso XI (1312-1350), Consejo Superior de Investigaciones CientíficasMinisterio de Defensa, Madrid, 2012.

Arias Guillén, Fernando, “'En Servicio de Dios e nuestro'. Complementariedad y tensión entre Reconquista y Cruzada durante el reinado de Alfonso XI", Guerra Santa y Cruzada en el Estrecho. El Occidente peninsular en la primera mitad del siglo XIV, Carlos de Ayala Martínez, Santiago Palacios Ontalva y Martín F. Ríos Saloma (coords.), Sílex Ediciones, Madrid, 2016, pp. 65-87.

Aurell, Martin "Messianisme royal de la Couronne d'Aragon (14 $15^{\mathrm{e}}$ siècles)", Annales. Histoire, Sciences Sociales, 52/1 (1997), pp. 119-155.

Ayala Martínez, Carlos de, "Órdenes militares y guerra santa. Reconquista y cruzada en el Occidente peninsular (siglos XII-XV)”, El mundo de los conquistadores, Martín F. Ríos Saloma (ed.), Instituto de Investigaciones Históricas. Universidad Nacional Autónoma de México/Sílex Ediciones, Ciudad de México/Madrid, 2015, pp. 355-373. Ayala Martínez, Carlos de, Henriet, Patrick, Palacios Ontalva, J. Santiago (dir.), Orígenes y desarrollo de la guerra santa en la Península Ibérica. Palabras e imágenes para una legitimación (siglos X-XIV), Casa de Velázquez, Madrid, 2016,

BAloup, Daniel, "Reconquête et croisade dans la Chronica Adefonsi imperatoris (ca. 1150)", Cahiers d'Études Hispaniques Médiévales, 25 (2002), pp. 453-480.

BARTLETt, Robert, The Making of Europe: Conquest, Colonization and Cultural Change, 950-1350, Princeton University Press, Princeton, 1993 ( $1^{\text {a }}$ ed. en español, Universitat de València, Valencia, 2003).

BAschet, Jérôme, La civilisation féodale. De l'an mil à la colonisation de l'Amérique, Aubier, París, 2004 ( $1^{\mathrm{a}}$ ed. en español, Fondo de Cultura Económica, Ciudad de México, 2009).

Belenguer Cebríà, Ernest, Fernando el Católico. Un monarca decisivo en las encrucijadas de su época, Península, Barcelona, 1999.

BÉNAT-TACHOT, Louise, “Figura y configuración de ‘enemigo americano’ en las crónicas de Indias (Historia general y natural de las Indias de Gonzalo Fernández de Oviedo y la Historia de las Indias de Francisco López de Gómara)", en Las teorías de la guerra justa en el siglo XVI y sus expresiones contemporáneas, Gilles Bataillon, Gilles Bienvenu, Ambrosio Velasco Gómez (dir.), Centro de estudios mexicanos y centroamericanos, Ciudad de México, 1998, pp. 93-124. < https://books.openedition.org/cemca/556 > (12-12-2018).

BÉNAT-TACHOt, Louise, "Gonzalo Fernández de Oviedo y la gesta de los 'cortesanos", en Miradas sobre Hernán Cortés, Carmen Martínez Martínez, Alicia Mayer González (coord.), Iberoamericana/Veurvert, Madrid, pp. 119-150. 
Bernard, Carmen, Gruzinski, Serge, De l'idolatrie. Une archéologie des sciences réligiéuses, Éditions de Seuil, París, 1988.

Bolaños CÁrdenas, Álvaro Félix, "La crónica de Indias de Fernández de Oviedo: ¿Historia de lo general y natural, u obra didáctica?”, Revista de Estudios Hispánicos, 25 (1991), pp. 15-33.

Brading, David, Orbe indiano. De la monarquía católica a la república criolla 14921867, Ciudad de México: Fondo de Cultura Económica, Ciudad de México, 1991. (1 ${ }^{\mathrm{a}}$ ed. en inglés, Cambridge University Press, Cambridge, 1991).

Bronisch, Alexander Pierre, Reconquista y guerra santa. La concepción de la guerra en la España cristiana desde los visigodos hasta comienzos del siglo XII, Universidad de Granada, Granada, 2006.

Bronisch, Alexander Pierre, "La (sacralización de la) guerra en las fuentes de los siglos X y XI y el concepto de guerra santa", Orígenes y desarrollo de la guerra santa en la Península Ibérica. Palabras e imágenes para una legitimación (siglos X-XIV), Carlos de Ayala Martínez, Patrick Henriet, J. Santiago Palacios Ontalva (dir.), Casa de Velázquez, Madrid, 2016, pp. 9-29.

CAstillo CÁceres, Fernando, "La caballería y la idea de la guerra en el siglo XV: el Marqués de Santillana y la batalla de Torote", Medievalismo: Boletín de la Sociedad Española de Estudios Medievales, 8 (1998), pp. 79-110.

Coello de la Rosa, Alexandre, "El héroe cidiano en la conquista de San Juan de Puerto Rico según la Historia General y Natural de las Indias de Gonzalo Fernández de Oviedo y Valdés (1511-1513)", Anales de Literatura Hispanoamericana, 34, (2005), pp. 87-109.

Coello de la Rosa, Alexandre, "Historias naturales y colonialismo: Gonzalo Fernández de Oviedo y José de Acosta", Illes i Imperis, 8, (2006), pp. 45-67.

Coello de la Rosa, Alexandre, Historia y ficción. La escritura de la Historia general y natural de las Indias de Gonzalo Fernández de Oviedo y Valdés (1478-1557), Universitat de València, Valencia, 2012.

Courcelles, Dominique de, Escribir historia, escribir historias en el mundo hispánico, Universidad Nacional Autónoma de México. Instituto de Investigaciones Históricas, Ciudad de México, 2009.

CuART Moner, Baltasar, "La larga marcha hacia las historias de España en el siglo XVI" La construcción de las historias de España, Ricardo García Cárcel (ed.), Marcial Pons, Madrid, 2004, pp. 45-126.

Duran Grau, Eulàlia, y Requesens, Joan, Profecia i poder al renaixement. Texts profétics catalans favorables a Ferran el Catòlic, Edicions 3i4, Valencia, 1997.

Echevarría Arsuaga, Ana, "Enrique IV de Castilla, un rey cruzado", Espacio, Tiempo y Forma, Serie III, Historia Medieval, 17(2004), pp. 143-156.

Fernández Gallardo, Luis, "Guerra santa y cruzada en el ciclo cronístico de Alfonso XI”, En la España medieval, 33 (2010), pp. 43-74. 
Fernández Gallardo, Luis, “Alonso de Cartagena y el debate sobre la caballería en la Castilla del siglo XV", Espacio, tiempo y forma. Serie III, Historia medieval, 26 (2013), pp. 77-118.

Fernández Gallardo, Luis, "Los Godos en la memoria histórica castellana del medievo", Antiquité tardive: revue internationale d'histoire et d'archéologie, 23 (2015), pp. 261-268.

Fernández-Ordóñez, Inés (coord.), Alfonso X el Sabio y las Crónicas de España, Universidad de Valladolid, Valladolid, 2001.

Fernández de Córdova Miralles, Álvaro, "El «Rey Católico» de las primeras Guerras de Italia. Imagen de Fernando II de Aragón y V de Castilla entre la expectación profética y la tensión internacional", Medievalismo. Boletín de la Sociedad Española de Estudios Medievales, 25 (2015), pp. 197-232.

Fernández de Córdova Miralles, Álvaro, "El «otro príncipe»: piedad y carisma de Fernando el Católico en su entorno cortesano", Anuario de Historia de la Iglesia, 26 (2017), pp. 15-70.

FLori, Jean, La guerre sainte. La formation de l'idée de croisade dans l'Occident chrétien, Aubier, París, 2001 ( $1^{\mathrm{a}}$. ed. en español, Trotta Editorial, Madrid, 2003).

FLORI, Jean, Guerre sainte, jihad, croisade. Violence et religion dans le christianisme et l'islam, Seuil, París, 2002 (1ª . ed. en francés, Universidad de Granada, Granada, 2004).

FunEs, Leonardo, "De Alfonso el Sabio al Canciller Ayala: variaciones del relato histórico (Conclusiones del seminario dictado en la Universidad de Buenos Aires, agosto-noviembre de 2002)", Memorabilia. Boletín de Literatura Sapiencial, 7 (2003), $<$ http://parnaseo.uv.es/memorabilia/memorabilia7/funes/funes._not.htm> (12-12-2018).

FunEs, Leonardo, "De la crónica medieval a la crónica de Indias: algunas reflexiones sobre la escritura de la historia en los umbrales de la Modernidad", Actas del IX Congreso Argentino de Hispanistas "El Hispanismo ante el Bicentenario", celebrado en La Plata del 27 al 30 de abril de 2010, María Mercedes Rodríguez Temperley, Santiago Disalvo et alii (eds.), Asociación Argentina de Hispanistas/Universidad Nacional de La Plata, La Plata, 2010, <http://ixcah.fahce.unlp.edu.ar/actas> (12-05-2018).

García Fitz, Francisco, La Reconquista, Universidad de Granada, Granada, 2010.

Gómez Moreno, Ángel, "La militia clásica y la caballería militar: las lecturas de re militari entre el Medievo y el Renacimiento", Evphrosine. Revista de Filología Clásica, 23 (1995), pp. 83-97.

Gómez Redondo, Fernando, "Historiografía medieval: constantes evolutivas de un género", Anuario de Estudios Medievales, 19 (1989), pp. 3-15.

Gómez Redondo, Fernando, Historia de la prosa medieval castellana (4 vols.), Cátedra, Madrid, 1998-2007.

Gómez Redondo, Fernando, Historia de la prosa medieval castellana. II (El desarrollo de los géneros. La ficción caballeresca y el orden religioso), Cátedra, Madrid, 1999. 
Gómez Redondo, Fernando, "La construcción del modelo de crónica real", Alfonso $X$ el Sabio y las crónicas de España, Inés Fernández Ordóñez (dir.), Universidad de Valladolid, Valladolid, 2001, pp. 133-158.

Gómez Redondo, Fernando, Historia de la prosa medieval castellana. IV (El reinado de Enrique IV. El final de la Edad Media. Conclusiones. Guía de lectura. Apéndices. Índices), Cátedra, Madrid, 2007.

Gómez Redondo, Historia de la prosa de los Reyes Católicos: el umbral del Renacimiento (2 vols.), Cátedra, Madrid, 2012.

GonzÁlez Boixo, José Carlos, "Hacia una definición de las crónicas de Indias", Anales de Literatura Hispanoamericana, 28 (1999), pp. 227-237.

GonzÁlez DíAz, Soledad, “Genealogía de un origen: Túbal, el falsario y la Atlántida en la Historia de los Incas de Pedro Sarmiento de Gamboa", Revista de Indias, 255 (2012), pp. 497-526.

GonzÁlez EchevarRÍA, Roberto, "Humanismo, retórica y las crónicas de la conquista", Historia y ficción en la narrativa hispanoamericana, Alejo Carpentier, Roberto González Echevarría et alii, Monte Ávila, Caracas, Editores, 1984, pp. 149-166.

GonzÁlez SÁnchez, Santiago, Los recursos militares de la monarquía castellana a comienzos del siglo XV. Las campañas granadinas del Infante D. Fernando. Setenil y Antequera (1407-1410), Dykinson, Madrid, 2016.

Green JR., James Ray, "La retórica y la crónica de Indias: el caso de Bernal Díaz del Castillo", Actas del octavo Congreso de la Asociación Internacional de Hispanistas, celebrado en Brown University, Providence Rhode Island, del 22 al 27 de agosto de 1983, Ediciones Istmo, Madrid, 1986, pp. 645-651.

Grunberg, Bernard, L'univers des conquistadores. Les hommes et leur conquête dans le Mexique du XVIe siècle, Éditions L'Harmattan, París, 1993.

GruZINSKI, Serge, La colonisation de l'imaginaire. Sociétés indigènes et occidentalisation dans le Mexique espagnol XVe-XVIIIe siècle, Gallimard, París, 1988 ( $1^{\mathrm{a}}$ ed. en español, Fondo de Cultura Económica, Ciudad de México, 1991).

Henriet, Patrick, "La guerra contra el Islam: una guerra santa, pero ¿según qué criterios?", El mundo de los conquistadores, Martín F. Ríos Saloma (ed.), Instituto de Investigaciones Históricas. Universidad Nacional Autónoma de México/Sílex Ediciones, Ciudad de México/Madrid, 2015, pp. 287-306.

KAGAN, Richard, Los cronistas y la Corona. La política de la historia de España en las Edades Media y Moderna, Marcial Pons, Madrid, 2010.

Koнut, Karl (ed.), Narración y reflexión. Las crónicas de Indias y la teoría historiográfica, El Colegio de México, Ciudad de México, 2007.

LAdero Quesada, Miguel Ángel, Castilla y la conquista del reino de Granada, Universidad de Valladolid, Valladolid, 1967. 
Ladero Quesada, Miguel Ángel, La guerra de Granada (1482-1491), Diputación Provincial de Granada, Granada, 2001.

Ladero Quesada, Miguel Ángel, Las Guerras De Granada en el Siglo XV, Ariel, Barcelona, 2002.

LAdero Quesada, Miguel Ángel, "La guerra del Estrecho", Guerra y diplomacia en la Europa occidental, 1280-1480. XXXI Semana de Estudios Medievales de Estella. 19 al 23 de julio de 2004, Gobierno de Navarra, Pamplona, 2005, pp. 255-294.

Ladero Quesada, Miguel Ángel, La España de los Reyes Católicos, Alianza Editorial, Madrid, 2014 (1 $1^{\text {a }}$ ed., 1999).

LeÓn-Portilla, Miguel, Visión de los vencidos. Relaciones indígenas de la Conquista, Universidad Nacional Autónoma de México, Ciudad de México, 1959.

LeOnARD, Irving A., Books of the Brave: Being an Account of Books and of Men in the Spanish Conquest and Settlement of the Sixteenth-Century New World, University of California Press, Berkeley, 1992, <http://ark.cdlib.org/ark:/13030/ft1f59n78v/> (1212-2018).

Leroy, Béatrice, L'historien et son roi. Essai sur les chroniques castillanes, XIV-XVe siècles, Casa de Velázquez, Madrid, 2013.

López Estrada, Fernando, "La retórica en las Generaciones y semblanzas de Fernán Pérez de Guzmán", Revista de Filología Española, 30 (1946), pp. 310-352.

Manzano Rodríguez, Miguel Ángel, La intervención de los Benimerines en la Península Ibérica, Consejo Superior de Investigaciones Científicas, Madrid, 1991.

Maravall, José Antonio, El concepto de España en la Edad Media, Centro de Estudios Constitucionales, Madrid, 1981.

Martín, José-Luis, Enrique IV de Castilla, Rey de Navarra, príncipe de Cataluña, Nerea, Hondarribia, 2003.

Mas Chaо, Andrés, "La formación militar del Rey Católico", Los reinos hispánicos ante la Edad Moderna, Estado Mayor del Ejército, Madrid, 1992, volumen II, pp. 225-232. Melo CARrasco, Diego, Las alianzas y negociaciones del sultán: un recorrido por la historia de las "relaciones internacionales" del Sultanato Nazarí de Granada (siglos XIII-XV), Editum, Murcia, 2015.

Mendiola Mejía, Alfonso, Retórica, comunicación y realidad. La construcción retórica de las batallas en las crónicas de la conquista, Universidad Iberoamericana, Ciudad de México, 2003.

Mignolo, Walter, "Cartas, crónicas y relaciones del descubrimiento y la conquista", Historia de la literatura hispanoamericana. Tomo I. Época colonial, Luis Íñigo Madrigal (coord.), Cátedra, Madrid, 1982, pp. 57-116.

MiLhou, Alain, Colón y su mentalidad mesiánica en el ambiente franciscanista español, Casa-Museo de Colón, Valladolid, 1983. 
MuÑoz Gómez, Víctor, "De Medina del Campo a Zaragoza: un periplo por las devociones «políticas» de un príncipe castellano bajomedieval (el infante Fernando de Antequera, 1380-1416)", eHumanista. Journal of Iberian Studies, 24 (2013), pp. 375-395.

MuÑoz Gómez, Víctor, "La guerra contra el Islam en el proyecto político de Fernando «el de Antequera», infante de Castilla y rey de Aragón (1380-1416)", El mundo de los conquistadores, Martín F. Ríos Saloma (ed.), Instituto de Investigaciones Históricas. Universidad Nacional Autónoma de México/Sílex Ediciones, Ciudad de México/Madrid, 2015, pp. 399-436.

MuÑoz Gómez, Víctor, Fernando "el de Antequera” y Leonor de Alburquerque (13741435). Una Historia de Poder en la Península Ibérica a finales de la Edad Media, Editorial Universidad de Sevilla, Sevilla, 2016.

MuÑoz Gómez, Víctor, "La construcción de un modelo de liderazgo militar en la Castilla bajomedieval y su proyección americana", Reti Medievali Rivista, 20/2 (2019), <http:// www.rmojs.unina.it/index.php/rm/article/view/6261/7399> (30- 09-2019)..

Nieto Soria, José Manuel, Ceremonias de la realeza. Propaganda y legitimación en la Castilla Trastámara, Editorial Nerea, Madrid, 1993.

Nieto Soria, José Manuel, "El ciclo ceremonial de la batalla de La Higueruela (1431)", Estudios de Historia de España, 12/2 (2010), pp. 389-404.

Nussbaum, María Fernanda, Claves del entorno ideológico del Poema de Alfonso XI, Sociedad Suiza de Estudios Hispánicos, Lausanne, 2012.

O’Callaghan, Joseph, Reconquest and Crusade in Medieval Spain, University of Pennsylvania, Filadelfia, 2003.

O’Gorman, Edmundo, Cuatro historiadores de Indias. Siglo XVI. Pedro Mártir de Anglería, Gonzalo Fernández de Oviedo y Valdés, Fray Bartolomé de Las Casas, Joseph de Acosta, Sep/Setentas, Ciudad de México, 1979.

Pastrana Flores, Gabriel Miguel, Historias de la conquista. Aspectos de la historiografía de tradición náhuatl, Universidad Nacional Autónoma de México, Ciudad de México, 2009.

Peinado Santaella, Rafael G., “"Christo pelea por sus castellanos»: el imaginario cristiano de la Guerra de Granada”, Las tomas: antropología histórica de la ocupación territorial del reino de Granada, José González Alcantud y Manuel Barrios Aguilera, Manuel (eds.), Diputación de Granada, Granada, 2000, pp. 453-524.

Peinado Santaella, Rafael G., Guerra santa, cruzada y yihad en Andalucía y el reino de Granada (siglos XIII-XV), Universidad de Granada, Granada, 2017.

PelÁez Rovira, Antonio, El emirato nazarí de Granada en el siglo XV: dinámica política y fundamentos sociales de un estado andalusí, Universidad de Granada, Granada, 2009. Perez, Joseph, Isabel y Fernando. Los Reyes Católicos, Nerea, Hondarribia, 1988.

Pérez de Tudela y Bueso, Juan, "Estudio preliminar", Historia general y natural de las Indias, Gonzalo Fernández de Oviedo, Atlas, Madrid, 1959. 
Porras Arboledas, Pedro A., Juan II (1406-1454), Diputación Provincial de Palencia, Palencia, 1993.

Porrinas GonzÁlez, David, "Guerra santa y cruzada en la literatura del Occidente peninsular medieval (siglos XI-XIII)”, Orígenes y desarrollo de la guerra santa en la Península Ibérica. Palabras e imágenes para una legitimación (siglos X-XIV), Carlos de Ayala Martínez, Patrick Henriet, J. Santiago Palacios Ontalva (dir.), Casa de Velázquez, Madrid, 2016, pp. 69-86.

Pupo Walker, Enrique, La vocación literaria del pensamiento histórico en América, Gredos, Madrid, 1982.

Ribot García, Luis, VAldeón Baruque, Julio y Maza Zorrilla, Elena (eds.), Isabel La Católica y su época. Actas del Congreso Internacional, Valladolid-Barcelona-Granada, 15 a 20 de noviembre de 2004, Universidad de Valladolid, Valladolid, 2007.

Ríos Saloma, Martín. F., "El mundo mediterráneo en la Edad Media y su proyección en la conquista de América: cuatro propuestas para la discusión", Históricas: Boletín del Instituto de Investigaciones Históricas, 90 (2011), pp. 2-15.

Ríos SAloma, Martín. F., La reconquista: una construcción historiográfica (siglos XVI$X I X)$, Marcial Pons/Universidad Nacional Autónoma de México. Instituto de Investigaciones Históricas, Madrid/Ciudad de México, 2011.

Ríos Saloma, Martín. F., "La Edad Media Europea en perspectiva atlántica. Reflexiones a propósito de la legitimación de la guerra de conquista", Hacer historia desde el medievalismo. Tendencias. Reflexiones. Debates, Víctor Muñoz Gómez, Eduardo Aznar Vallejo (eds.), Universidad de la Laguna, San Cristóbal de La Laguna, 2016, pp. 313-335. Ríos Saloma, Martín. F., "El mundo mediterráneo en la Edad Media y su proyección en la conquista de América: cuatro propuestas para la discusión”, Dinámicas de conquista en las fronteras de la Monarquía Hispánica”, Intus Legere Historia, 12/2 (2018), pp. 187-213. Ríos Saloma, Martín. F., La Reconquista en la historiografía española contemporánea, Sílex Ediciones/Universidad Nacional Autónoma de México. Instituto de Investigaciones Históricas, Madrid/Ciudad de México 2013.

Ríos Saloma, Martín F., "Una nueva historia para un mundo: los modelos historiográficos entre Italia y Nueva España" El Renacimiento italiano visto desde América Latina, Clara Bargellini (ed.), Universidad Nacional Autónoma de México. Instituto de Investigaciones Estéticas, Ciudad de México, 2018. < http://www.ebooks.esteticas. unam.mx/items/show/55 > (12-12-2018).

RodríGUEZ VELASCO, Jesús. D., El debate sobre la caballería en el siglo XV. La tratadística caballeresca castellana en su marco europeo, Junta de Castilla y León, Valladolid, 1996. Rodríguez-Picavea Matilla, Enrique, "Diplomacia, propaganda y guerra santa en el siglo XIV: la embajada castellana a Aviñón y la elaboración del discurso ideológico", Anuario de Estudios Medievales, 40/2 (2010), pp. 765-789. 
Sánchez-Albornoz, Claudio, La Edad Media española y la empresa de América, Instituto de Cultura Hispánica, Ediciones Cultura Hispánica del Instituto de Cooperación Iberoamericana, Madrid, 1983.

Serna, Mercedes (ed.), Crónicas de Indias. Antología, Cátedra, Madrid, 2003 (1ª ed., 2000).

Spiegel, Gabrielle M., "History, Historicism, and the Social Logic of the Text in the Middle Ages", Speculum, 55 (1990), pp. 59-86.

Suarez Bilbao, Fernando, "La guerra de Granada en tiempos de Enrique III, La península ibérica en la era de los descubrimientos (1391-1492). Actas III Jornadas HispanoPortuguesas de Historia Medieval, Sevilla, 25-30 de noviembre de 1991, Consejería de Cultura, Universidad de Sevilla, Sevilla, 1997, volumen II, pp. 1421-1436.

SuÁREZ FERNÁNDEZ, Luis, Juan II y la frontera de Granada, Universidad de ValladolidEscuela de Historia Moderna del CSIC, Valladolid, 1954.

TATE, Robert B., Ensayos sobre la historiografía peninsular del siglo XV, Gredos, Madrid, 1970.

Tinoco DíAz, J. Fernando, “Aproximación a la cruzada en la Baja Edad Media peninsular: reflexiones sobre la guerra de Granada", Revista Universitaria de Historia Militar On-Line, 1/1 (2012), pp. 79-99.

Tinoco DíAz, J. Fernando, La Cruzada en las fuentes cronísticas castellanas de la guerra de Granada, Tesis doctoral defendida en la Universidad de Extremadura, 2017.

Torró, Josep, “Pour en finir avec la 'Reconquête'. L'occupation chrétienne d'al-Andalus, la soumission et la disparition des populations musulmanes (XIIe-XIIIe siècle)", Cahiers d'Histoire. Revue d'histoire critique, 78 (2000), pp. 79-97.

Torró, Josep, "Partners-in-arms. Medieval Military Associations: From the Iberian cabalgada to the American entrada", From Al-Andalus to the Americas (13th-17th Centuries). Destruction and Construction of Societies, Thomas Glick, Antonio Malpica et alii (eds.), Brill, Leiden-Boston, 2018, pp. 19-77.

Turner, Guillermo, Los soldados de la Conquista: herencias culturales, Ediciones del Tucán de Virginia. Instituto Nacional de Antropología e Historia, Ciudad de México, 2013.

Valdaliso Casanova, Covadonga, "La legitimación dinástica en la historiografía Trastámara”, Res Pública. Revista de Filosofía Política, 8 (2007), pp. 307-321.

Valdaliso Casanova, Covadonga, Historiografía y legitimación dinástica. Análisis de la Crónica de Pedro I de Castilla, Servicio de Publicaciones de la Universidad de Valladolid, Valladolid, 2010.

Valdaliso Casanova, Covadonga, "Discursos de legitimación de la dinastía Trastámara (1366-1388)", Ruptura i legitimació dinàstica a l'Edat Mitjana, Flocel Sabaté y Maite Pedrol (coords.), Pagès Editors, Lleida, 2015, pp. 127-142. 
Vaquero, Mercedes, El 'Poema de Alfonso XI': ¿crónica rimada o épica, Ann Arbor, University of Michigan. Dissertation Information Service, 1988.

Verlinden, Charles, The Beginnings of the Modern Colonization, Cornell University Press, Ithaca, 1970.

WARD, Aengus (ed.), Teoría y práctica de la historiografia medieval ibérica, Birmingham University Press, Birmingham, 2000.

Warmington, Flynn, "The Ceremony of the Armed Man: The Sword, the Altar, and the L'homme armé Mass", Antoine Busnoys. Method, Method, Meaning, and Context in Late Medieval Music, Paula Higgins (ed.), Oxford University Press, Oxford, 2000, pp. 89-130.

Weber de Kurlat, Frida, "Estructura novelesca del Amadis de Gaula", Revista de Literatura Moderna, 5 (1966), pp. 29-54.

Weckmann, Luis, La herencia medieval en México, Fondo de Cultura Económica, Ciudad de México, 1984. 